\title{
Evaluation of Groundwater Quality for Drinking and Irrigational Purposes in a Coastal Alluvial Aquifer using Multivariate Statistical Approach: A Case Study from West Godavari Delta, Andhra Pradesh, India
}

Swarna Latha P ( $\square$ dr.swarnapisupati@gmail.com )

Andhra University https://orcid.org/0000-0002-0811-2520

Research Article

Keywords: Groundwater quality, Alluvial aquifer, Hydrochemical indices, PCA/FA, Multivariate statistics, Godavari delta, Coastal Andhra

Pradesh, India

Posted Date: May 6th, 2021

DOI: https://doi.org/10.21203/rs.3.rs-474801/v1

License: (c) (i) This work is licensed under a Creative Commons Attribution 4.0 International License. Read Full License 


\section{Abstract}

The present study investigates the groundwater quality for drinking and irrigational purposes in a coastal aquifer of the West Godavari delta region based on geochemical evaluation and multivariate statistical analysis. The study area is underlain by the Quaternary sediments with unconsolidated and semi consolidated sand, silt and clay formation. The significant hydro chemical facies of groundwater observed throughout the study is $\mathrm{Na}-\mathrm{Mg}-\mathrm{Cl}-\mathrm{HCO}_{3}, \mathrm{Na}-\mathrm{Cl}-\mathrm{HCO}_{3}$, and $\mathrm{Mg}-\mathrm{Na}-\mathrm{Cl}-\mathrm{HCO}_{3}{ }^{-}$. The results revealed that the area occupied high salinity ground waters controlling by evaporation and also rock weathering-solubilization to some extent. The abundance of chemical parameters are $\mathrm{Na}^{+}>$ $\mathrm{K}^{+}>\mathrm{Mg}^{2+}>\mathrm{Ca}^{2+}=\mathrm{Cl}^{-}>\mathrm{HCO}_{3}{ }_{3}>\mathrm{SO}_{4}{ }^{2-}>\mathrm{NO}_{3}{ }^{2-}$. The analyzed water quality parameters were compared with the Bureau of Indian Standards for their suitability for domestic usage. The chemical constituents of samples TA (85\%), TDS (100\%), TH (83\%), $\mathrm{Mg}^{2+}(91 \%), \mathrm{Cl}^{-}(81 \%)$, and $\mathrm{SO}_{4}{ }^{2-}(12 \%)$ exceeded the limits, hence, are unsuitable for drinking. The irrigation suitability parameters such as $\mathrm{Na} \%, \mathrm{SAR}, \mathrm{RSC}, \mathrm{PI}, \mathrm{CAl}, \mathrm{KR}$, and CCR were calculated for assessing groundwater for agriculture purposes. Most of the samples show excess values, which revealed that the ground waters was not even suitable for irrigation because of providing low productivity. However, some samples ranging between the good and moderate categories can be used for irrigation with proper management. The multivariate statistical analysis was performed to understand the relationship of chemical constituents presents in groundwater. TDS is highly correlated with $\mathrm{EC}, \mathrm{TH}, \mathrm{Ca}^{2+}, \mathrm{Mg}^{2+}, \mathrm{Na}^{+}, \mathrm{K}^{+}$, $\mathrm{HCO}^{-}$, and $\mathrm{Cl}^{-}$. Principal component analysis (PCA) applied to the data sets showed that the first three PCs accounted for $65 \%$ of total variance cumulatively $94.5 \%$ for a total of seven PCs. It represents the quality of groundwater deviation is possibly attributed to various anthropogenic and geogenic factors, rock-water interactions and ion-exchange processes in groundwater. The uncontrolled drawl of subsurface waters and aqua forming at an advanced rate when compare to recharge led to the coastal aquifers in critical stage, particularly in the study region Godavari delta of Andhra Pradesh state in southern India.

\section{Introduction}

Groundwater is a vital natural resource and has a significant role in the global economy. For irrigation purposes, groundwater is a reliable source of water and can be used in a flexible manner (USGS, 2001). According to World Bank (2012), the largest consumer of groundwater in the world is India, with an estimated annual groundwater use of $230 \mathrm{~km} 3$. Due to the pressure created over hydrologic and hydrogeological systems about the impact of climate change the quality of groundwater will mainly degrade in coastal areas. Seawater intrusion and salinization of groundwater because of overexploitation of freshwater aquifers will establish a negative water balance in the coastal regions (Gleeson and Tom, 2012). Hydro chemical studies of groundwater have vigorously been conducted by several researchers globally to identify and interpret the human-induced impact on groundwater chemistry (Loh et al. 2019; He et al. 2019; Wagh et al., 2018; Li et al., 2016, Sarikhani et al. 2015; Brindha and Kavitha, 2015; Aly et al., 2014; Gibrilla et al. 2011; Sahu and Sikhdar, 2008; Diana et al., 2017). The multi-usage of groundwater for drinking, agricultural and industrial purposes, fisheries and energy productions depend considerably on their quality (Iscen et al. 2008). The soil structure and crop yields are adversely affected by the presence of salts in irrigation waters. Arid and semi-arid climate regions are particularly vulnerable to salinity because of variations in rainfall and temperatures, which are leading to high evaporation (Houatmia et al., 2016; Jalali, 2007). The soils of agrarian areas were created environmental problems like water resource's contaminants and health risks in human beings due to vigorous usage of fertilizers and agrochemicals (Shindo et al. 2006; Scanlon et al. 2007; Jiang et al. 2009). Zakaria et al. (2020) conducted groundwater quality studies in the Anayari catchment area which is predominantly dependent on groundwater for agricultural purposes. They found that the water containing a low percentage of $\mathrm{Na}+$ with moderate salinization can be usually used for irrigation purposes without any prior treatment. In recent years, with an increasing number of chemical and physical variables of groundwater, a wide range of conventional tools and techniques of statistical methods applied for proper analysis and interpretation of data (Belkhiri et al. 2010; Machiwal and Jha, 2010). Multivariate statistical analysis was applied in hierarchal cluster analysis by some researchers, being a simple approach to distinguish the multivariate similarities in groundwater quality. Principal Component Analysis (PCA)/Factor Analysis (FA) and Cluster Analysis (CA) explains the data set matrixes for understanding environmental systems and quality of water influenced either by natural or anthropogenic conditions (Lee et al. 2001; Ravikumar et al. 2017; Sandeep et al. 2020; Blake et al., 2016; Dudeja et al. 2011; Guggenmos et al. 2011; Khelif and Boudoukha, 2018; Sayad et al. 2017; Paul et al., 2019; Subyani and Ahmadi, 2010). For analyzing large datasets on water quality with minimum loss of vital information can be employed using multivariate statistical techniques (Simeonov et al. 2003; Jauhir et al. 2011; Gulgundi and Shetty. 2018). The alluvial aquifer system is the dominant type of aquifer in the coastal area. The coastal alluvial aquifer is relatively vulnerable to contamination by seawater. It is hard to restore its fresh groundwater condition, which makes groundwater unsuitable for drinking as well as agriculture use (Jeen et al., 2001; Chidambaram et al., 2009; Mohapatra et al., 2011; Swarna Latha and Nageswara Rao, 2012; Guler et al., 2012; Reddy, 2013; CGWB, 2014; Sajjil kumar, 2016; Alfrrah et al., 2018; Sivakarun et al., 2020). The conversion of agriculture and marshy lands into aqua farming which uses large-scale saline water from creeks, and urban-industrialization lead to the alteration of freshwater aquifers in coastal regions, thus understanding the hydro chemical characteristics of the coastal groundwater is essential to prevent saline intrusion and its associated problems (Prasanna et al., 2011; Thilagavathi et al., 2019). The residents of coastal regions in India are facing now severe drinking water 
quality problems in comparison with the other regions. Keeping this in view, the present study was carried out to evaluate the hydro chemical characteristics and groundwater quality and its suitability for domestic and irrigation purposes in an alluvial coastal aquifer using multivariate statistical techniques.

\section{Study area}

The study area is located within the West Godavari delta region of coastal Andhra Pradesh (AP) in Southern India. The district West Godavari of AP is bounded by the district's East Godavari in the North and Krishna in the South, Telangana State in the West and Bay of Bengal in the East. The area is under research lying between $16^{\circ} 19^{\prime} \mathrm{N}$ to $16^{\circ} 40^{\prime} \mathrm{N}$ latitudes and $81^{\circ} 19^{\prime} \mathrm{E}$ to $81^{\circ} 43^{\prime} \mathrm{E}$ longitudes (Fig. 1). It has a $23 \mathrm{~km}$ coastline covered by natural vegetation, cashew, casuarina and coconut plantations on its sandy tracts. The study area receives rainfall, mostly from the south-west monsoon (June to September), and the average annual rainfall recorded is about $875 \mathrm{~mm}$. The climate is maritime tropical humid noting with $20^{\circ} \mathrm{C}$ in December and $38^{\circ} \mathrm{C}$ in May. The River Godavari is a major river and its tributaries namely Tammileru, Yarrakalva and Ramileru are flowing through the West Godavari district and providing abundant water supply for vast tracts of agriculture fields and aquaculture ponds. The river Godavari bifurcates into Gautami Godavari and Vasishta Godavari in the district region. The Gautami Godavari river marks as a district boundary on the right side and drains through the present study area ultimately debouches into the Bay of Bengal at Antarvedi. The delta area is aided by the large canal system and numerous other drains. The oceanic saline water from creeks is also extensively used for aqua farming near the coastal tracts. The largest shallow freshwater lake in Asia is Kolleru Lake in the southwestern part with in the study area and designated as a wetland of worldwide importance under the international Ramsar Convention. The study area accommodates nearly 0.5 million population spreading over one major town and 79 villages. Agriculture and aquaculture are the predominant activities found throughout the study area. The area is known for the large-scale production of paddy, sugarcane, pulses, oilseeds, coconuts, etc., and it is considered to be one of the largest aqua farming regions of the country. The study area is infested by a huge number of fish and prawn ponds during the last three decades resulting in the ecological and environmental imbalance (Swarna Latha, 2018).

\section{General Geology and Geomorphology}

Geologically, the study area is underlain by the Quaternary sediments with unconsolidated to semi consolidated sand, silt and clay formations. In general, the delta sediments consist of brown, grey, gravelly sands and silty clay. The thickness of the sediments gradually increasing towards the sea and is of the order of $400 \mathrm{~m}$ in the Godavari delta (Raju et al., 1994; Ramesh, 2008). The quaternary sediments comprised of thick layers of alluvium, gravel and colluvial deposits, beach sand, kankar and soils of various types. Different geomorphic features such as flood plain, alluvial plain, levees, paleochannels, beach ridges, active tidal flats, mudflat, swamps, and backwater, etc. are observed. Flood plains are built up of alluvium carried by the river during floods and is deposited in the sluggish water. The flat or nearly level sloping grounds of these flood plains are yielding high groundwater potential zones. Beach ridges are low dunes formed as continuous mounds of beach materials (sand, gravel, shingle, etc.) parallel to the shoreline. Another important feature is tidal flats, which are characteristically extensive, nearly horizontal, marshy or barren stretch of lands alternately covered and uncovered by the rise and fall of the tides. It consists of unconsolidated sediments, mostly of mud and sand. Soils predominantly are in deep black clay and sandy; and some extent gravelly dark brown and silty soils. Groundwater extraction structures in the study region are mainly open, bore or tube wells. The average depth of the dug well recorded is 7 meters below the ground level $(\mathrm{m} \mathrm{bgl})$. Bore well depth varies from 10 to $65 \mathrm{~m}$. The average fluctuation of the water table is recorded at $0.91 \mathrm{~m}$ in the study area (CGWB, 2017).

\section{Materials And Methods}

A total of fifty eight (58) groundwater samples were collected with proper care from the bore wells covering the entire study area during May 2017 (Fig. 1). The $1 \mathrm{~L}$ polyethylene bottles were used for collecting groundwater and were properly rinsed with distilled water before carrying out the sampling. At the sampling location, the bottles were rinsed several times with the same bore well water to avoid any contamination before filling. These samples were cautiously sealed and labeled and taken to the laboratory for carrying out the analysis within a week. The samples were preserved by adding appropriate reagents in the laboratory by adopting standard protocols (APHA, 1998). pH, electrical conductivity (EC), total dissolved solids (TDS) were analyzed using multi parameter digital meter. Total alkalinity (TA), total hardness (TH), calcium $\left(\mathrm{Ca}^{2+}\right)$, bicarbonates $\left(\mathrm{HCO}_{3}{ }^{-}\right)$and chlorides $\left(\mathrm{Cl}^{-}\right)$were measured by titration method, sodium $\left(\mathrm{Na}^{+}\right)$and potassium $\left(\mathrm{K}^{+}\right)$by a flame photometer whereas sulphates $\left(\mathrm{SO}_{4}{ }^{2-}\right)$ were analyzed by using spectrophotometry. Magnesium $\left(\mathrm{Mg}^{2+}\right)$ was estimated by the formulae [TH$(2.5 \times \mathrm{CaH})] / 4.1$ (Todd and Mays 2005). The result of ionic balance shows that the error for groundwater samples was $\leq 10 \%$. The analytical results of chemical parameters of groundwater are presented in Table 1. Bureau of Indian Standards (BIS, 2012) were considered for comparing chemical constituents in groundwater for its utilization both domestic and agricultural purposes.

The following selected parameters were computed for assessing the groundwater suitability for irrigation purpose.

Page 3/24 


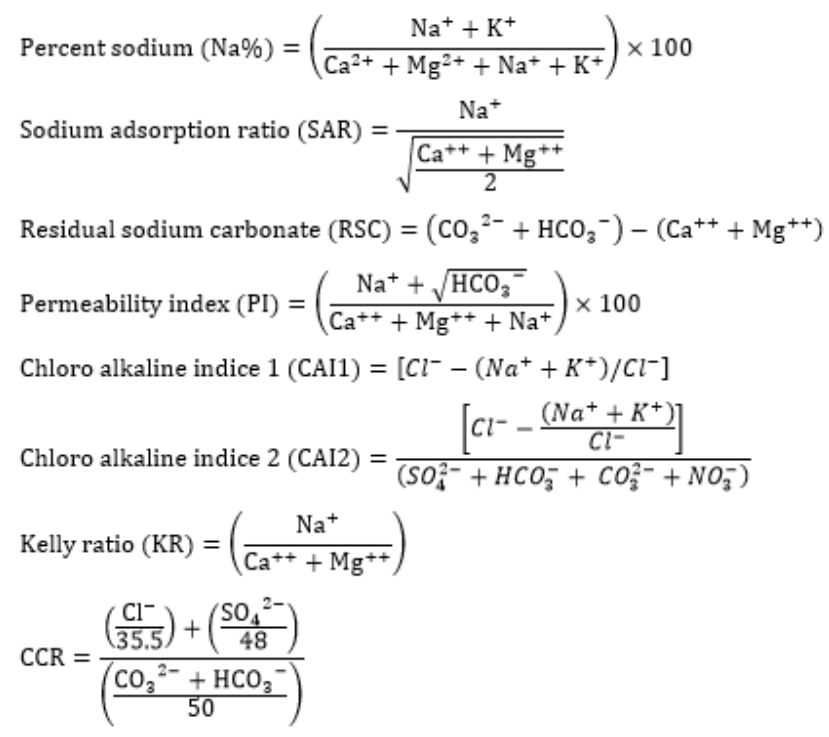

Where the concentration of ions used in the calculations is in meq/L except for KR and CR for which mg/L used. The results of all irrigation quality parameters are given in Table 2. Multivariate statistical analysis methods, including principal component analysis, factor analysis and correlation were used to analyze the groundwater chemistry characteristics. XLSTAT 2018 was utilized for preparing graphs and data table analysis. The Piper, USSL, Wilcox`s diagrams were generated using Aquachem 2014 software.

\section{Results And Discussion}

Box plot helps in summarizing the distribution of a data set by the median, the variation, the skewness, outliers and extreme values in a graphical form. From Fig. 2, it is noted that TA, EC, TDS, $\mathrm{Mg}^{2+}, \mathrm{HCO}_{3}^{-}, \mathrm{SO}_{4}{ }^{2-}$ are approaching normality. The data of the variables $\mathrm{Ca}^{2+}$, $\mathrm{Na}^{+}$, $\mathrm{Cl}^{-}$, and $\mathrm{NO}_{3}{ }^{2-}$ depart from a normal distribution only in the skewness. There are outliers for $\mathrm{pH}, \mathrm{TH}$ and $\mathrm{K}^{+}$but data depart from a normal distribution only in the skewness. The unexpected outliers are may be due to the usage of fertilizers in agricultural and aqua pond regions. The abundance of chemical parameters are as follows: $\mathrm{Na}^{+}>\mathrm{K}^{+}>\mathrm{Mg}^{2+}>\mathrm{Ca}^{2+}=\mathrm{Cl}^{-}>\mathrm{HCO}_{3}^{-}>\mathrm{SO}_{4}{ }^{2-}>\mathrm{NO}_{3}{ }^{2-}$.

\section{HYDRO CHEMICAL PROCESSES}

Piper (1944) plot explains the evolutionary trends of water quality parameters in order to classify the similarities and differences in the chemical composition of waters into certain water types. The ground waters were categorized into different hydro chemical facies based on major cations $\mathrm{Ca}^{2+}, \mathrm{Mg}^{2+}, \mathrm{Na}^{+}, \mathrm{K}^{+}$, and major anions $\mathrm{HCO}_{3}{ }^{-}, \mathrm{Cl}^{-}, \mathrm{SO}_{4}{ }^{2-}$ using Piper's trilinear diagram (Fig. 3). The prominent types shown are $\mathrm{Na}-\mathrm{Mg}-\mathrm{Cl}-\mathrm{HCO}_{3}, \mathrm{Na}-\mathrm{Cl}-\mathrm{HCO}_{3}$, and $\mathrm{Mg}-\mathrm{Na}-\mathrm{Cl}-\mathrm{HCO}_{3}{ }^{-} \cdot$ It can be observed from the plot that the majority of groundwater samples fall in the field of 4 suggesting that strong acids exceed weak acids. The exceeding primary salinity (field 7) and alkalies exceed alkaline earths (field 2) are also found (Table 3). The samples in the Na-Mg-Cl facies indicate the leaching of primary/secondary salts and exchange of ions from the clay deposits. The mechanism controlling the geochemical process of groundwaters with respect to atmospheric precipitation, rock-water interaction and evaporation, has been presented by Gibb`s plot (1970) for the present study (Fig. 4). The ratios of dominant cations $\left(\mathrm{Na}^{+}+\mathrm{K}^{+}\right) /\left(\mathrm{Na}^{+}+\mathrm{K}^{+}+\mathrm{Ca}^{2+}\right)$ and anions $\left(\mathrm{Cl}^{-} /\left(\mathrm{Cl}^{-}+\mathrm{HCO}_{3}^{-}\right)\right.$were plotted against the value of TDS. It is found that the most of sampling points fall towards evaporation dominance indicating the groundwater with high salinity controlled by evaporation and also rock weatheringsolubilization. Cation exchange is the influence factor controlling hydro chemical processes. The limited interaction of rock water generally includes the chemical weathering of the rocks, the precipitation dissolution of secondary carbonates and the exchange of ions between the water and the clay minerals.

\section{IONIC GROUNDWATER USE FOR DRINKING}

The chemical constituents present in the groundwater is showing a wide variation in different individual parameters (Table 1). The pH of groundwater samples ranged from 7.2 to 8.7, with a mean of 7.8, indicating the slightly alkaline nature of groundwater in the study area. pH generally varies between 6.0 and 8.5 and low pH allows to dissolve more minerals (Weiner 2000). The concentrations of physico-chemical parameters in ground waters and their effect upon human health are presented in Table 4.

The minimum and maximum values of alkalinity ranged from 124 to $466 \mathrm{mg} / \mathrm{L}$ with a standard deviation of 81.8 . Above $250 \mathrm{mg} / \mathrm{L}$ concentration of total alkalinity in the water gives an unpleasant taste (BIS 2012). Nearly $85 \%$ of the water samples in the study area contain 
alkalinity values higher than the desirable limits. The high alkalinity values for the study area are raised due to the action of carbonates on the basic materials on the soil which gives an unpleasant taste to water. EC fluctuated from 1675 to $3881 \mu \mathrm{g} / \mathrm{L} \mu \mathrm{S} / \mathrm{cm}$, with a mean of 2800 $\mu \mathrm{g} / \mathrm{L}$ while TDS ranged between 985 and $2283 \mathrm{mg} / \mathrm{L}$ with a mean of $1647 \mathrm{mg} / \mathrm{L}$. High EC explains that the more dissolved inorganic substances in the ionized form present on the water. EC of water is considered to be an indication of the total dissolved salt content (Hem, 1985). All the groundwater samples recorded above the desirable limits of TDS (more than $500 \mathrm{mg} / \mathrm{L}$ ), and $84 \%$ of samples have TDS > $2000 \mathrm{mg} / \mathrm{l}$ hence these cannot be recommended for drinking (BIS, 2012). TH as $\mathrm{CaCO}_{3}$ varied from 114 to $688 \mathrm{mg} / \mathrm{L}$ with a mean of 386 . There are ten samples that fall within the desirable limits and the remaining samples ( $83 \%$ of total samples $>300 \mathrm{mg} / \mathrm{L}$ ) to very hard water category. The cations $\mathrm{Ca}^{2+}, \mathrm{Mg}^{2+}, \mathrm{Na}^{+}$, and $\mathrm{K}^{+}$ranged from 11-69 mg/L, $10-139 \mathrm{mg} / \mathrm{L}, 98-414 \mathrm{mg} / \mathrm{L}, 29-143 \mathrm{mg} / \mathrm{L}, \mathrm{respectively}$. The anions $\mathrm{HCO}_{3}^{-}, \mathrm{Cl}^{-}, \mathrm{SO}_{4}{ }^{2-}$, and $\mathrm{NO}_{3}{ }^{2-}$ varied from $162-610 \mathrm{mg} / \mathrm{L}, 156-602 \mathrm{mg} / \mathrm{L}, 28-227 \mathrm{mg} / \mathrm{L}, 2-41 \mathrm{mg} / \mathrm{L}$, respectively. Calcium bicarbonate is the prime cause of the hardness in water. Concentrations of $\mathrm{Ca}^{2+}$ and $\mathrm{Mg}^{2+}$ are well below the permissible limits. In sea waters, magnesium present in large quantities and high magnesium in the groundwater causes scaling in boilers, pipes and water heaters, and abdominal disorders, etc. and is not desirable for domestic use. Higher values of $\mathrm{Na}^{+}$(mean $250 \mathrm{mg} / \mathrm{L}$ ) and K+ (mean $95.2 \mathrm{mg} / \mathrm{L}$ ) were found in the groundwater may be attributed to saline water intrusion, discharge of aquaculture wastewaters and domestic sewage. Normally, these ions become not toxic to humans. However, excess intake causes hypertension and vomiting, etc. Whereas $\mathrm{K}^{+}$is an essential element for plants and animals. $\mathrm{Cl}^{-}$directly relates to the mineral content of water and is mostly identified by salt taste in potable water. Only $19 \%$ of groundwater samples showed less than $250 \mathrm{mg} / \mathrm{L}$, which is acceptable for drinking as per BIS. It explains that the probable cause for the abnormal concentration of chloride is the seawater intrusion and rocks in the study region. $\mathrm{SO}_{4}{ }^{2-}$ concentrations in seven locations showed as slightly high above limits. All the samples of $\mathrm{NO}_{3}{ }^{2-}$ falls under permissible limits of BIS. Overall, the majority of water-quality parameters of the groundwater samples analyzed in the study area were recorded above desirable levels.

\section{IONIC GROUNDWATER USE FOR IRRIGATION}

In the study area, the groundwater samples were analyzed for monitoring the suitability of quality for irrigation purposes. It can be observed from Table 2, the groundwater recorded as high to very high salinity condition (Richards 1954). About $85 \%$ of total samples have recorded electrical conductivity very high $(>2,250 \mu \mathrm{S} / \mathrm{cm})$. High EC in the water proportionate to the salt content which explains that the groundwater can severely affect the plants and soils thus reducing productivity. Na\% ranged between 41 and 87.9 meq/L with a mean of 63 meq/L. Nearly $69 \%$ of water samples were found with high percent sodium (>60\%) thereby unsuitable even for irrigation (Ramakrishna 1998, Swarna Latha and Nageswara Rao, 2012). Twenty four samples out of $58, \mathrm{Cl}^{-} / \mathrm{HCO}_{3}{ }^{-}$ratio is shown above 2 , which indicate the possible signatures of seawater intrusion to the land as the area is adjoining to the coast and the aqua ponds are continuously being pumped by saline water (Desai et al. 1979). High sodium content may destroy the soil structure, and affect plants growth (Wilcox 1948). Only two samples (Nos. 54 and 55) falls under the permissible to doubtful category and the remaining all the samples are in doubtful to unsuitable category (Fig. 5 and Table 5). The SAR values in the study area vary from 2.0 to $13.2 \mathrm{meq} / \mathrm{L}$ and nearly $45 \%$ of sample's exhibit increase problems as SAR > 6 meq/l (Herman Bouwer 1978).

According to the U.S. Salinity Laboratory Diagram (USDA 1955), more than 80\% of the water samples comes under the fields of C4S2, C4S1, C4S3, C3S2 indicating high-very high salinity and low-high alkali water (Fig. 6 and Table 6). The groundwater is unsuitable for irrigation in the drainage restriction as it leads to low permeability and poor cultivable. RSC varied from -6.1 to 3.8 meq/L with a mean of -1.8 meq/L in the study area. More than $82 \%$ of samples shown negative values and are safe for irrigation purpose. The best irrigation practices must be adopted to use the marginal RSC water for irrigation. The high concentration of $\mathrm{Na}^{+}, \mathrm{Ca}^{2+}, \mathrm{Mg}^{2+}$ and $\mathrm{HCO}_{3}^{-}$in irrigation water can affect the soil's permeability condition. More than $80 \%$ of the groundwater samples unsuitable for irrigation purposes. (Donen 1964). The range of KR values is 0.7 to $8.5 \mathrm{mg} / \mathrm{L}$, and most of the groundwater samples (91\%) recorded above 1, hence, the groundwater is fit for irrigation (Kelley, 1951). The CR values (range $0.7-5.3 \mathrm{mg} / \mathrm{L}$ ) recorded in the study area indicating the corrosive nature of water thus it cannot be transported through the metal pipes.

\section{PRINCIPAL COMPONENT AND FACTOR ANALYSIS}

The data set of analyzed parameters was verified for variable reduction by PCA and FA using Kaiser-Meyer-Olkin and Bartlett's sphericity tests. The results of the KMO and $\rho$ were 0.58 and less than 0.001 , respectively, hence the data set was used for analysis (Wang et al. 2017). The results of the principal factors, eigenvalue, explained variance and vari max-rotated loads are summarized in Table 7. EC (0.92), TDS (0.92), $\mathrm{HCO}_{3}^{-}(0.71), \mathrm{TA}(0.69), \mathrm{TH}(0.69), \mathrm{Mg}^{2+}(0.6)$ in factor 1 while in factor $2, \mathrm{Na}^{+}(0.88)$ and $\mathrm{Cl}^{-}(0.88)$ were recorded. The first three PCs accounted for $65 \%$ of total variance cumulatively $94.5 \%$ for a total of 7 PCs. The scree plot showing the positive component loadings of all PCs is presented in Fig. 7. The first factor explained $33.3 \%$ of the total variance with strong positive loadings on $\mathrm{EC}, \mathrm{TDS}, \mathrm{TH}, \mathrm{HCO}_{3}{ }^{-} \mathrm{TA}^{\mathrm{T}}$ and

limited loading on $\mathrm{NO}_{3}{ }^{2-}$. This could be due to the influence of carbonate weathering as the main source of these minerals. Factor 2 
contributed $20.3 \%$ of the total variance with high positive loadings on $\mathrm{Na}^{+}$and $\mathrm{Cl}^{-}$which probably due to seawater intrusion. Factor 3 accounts for $10.8 \%$ of the total variance. The closely related parameters were $\mathrm{SO}_{4}{ }^{2-}$ and $\mathrm{K}^{+}$; this was probably due to the application of organic and inorganic fertilizers, manure and sewage. With the loading of $\mathrm{Mg}^{2+}$, factor 4 contributed $9.74 \%$ to the total variance; this indicates the impact of clay minerals and rock weathering. All the hydro chemical parameters applied by Pearson's correlation indicating that

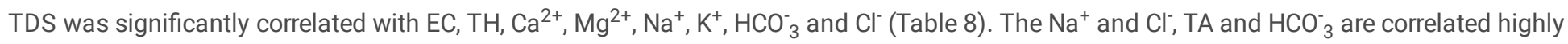
significant. It can be observed from the Table that these chemical components are the main source of TDS.

\section{Conclusions}

The evolution of groundwater chemistry was explained through geochemical plots, ionic ratios, bivariate scatter plots, principal component and factor analysis for the coastal aquifer of Southern India. The chemical constituents in the groundwater were determined for their suitability for drinking and irrigation purposes. The average ionic concentration found in the study area is $\mathrm{Na}^{+}>\mathrm{K}^{+}>\mathrm{Mg}^{2+}>\mathrm{Ca}^{2+}=\mathrm{Cl}^{-}>$ $\mathrm{HCO}^{-}{ }_{3}>\mathrm{SO}_{4}{ }^{2-}>\mathrm{NO}_{3}{ }^{2-}$. The high concentrations of $\mathrm{Na}^{+}, \mathrm{Cl}^{-}$, and $\mathrm{SO}_{4}{ }^{2-}$ found in the groundwater may be attributed to the dissolution of mineral phases in the aquifer systems. Bivariate scatter plots strongly supported the process of reverse ion exchange and seawater intrusion. PCA and FA explained that the factors responsible for the variation in the groundwater chemistry as weathering, leaching of secondary salts, reverse ion exchange, seawater intrusion, and agricultural return flow. All the groundwater samples were compared with BIS for potability indicating the groundwater in the study area is unfit for drinking in most of the areas. The quality indices for irrigation revealed that the groundwater studied in the locations is ranging between the good and moderate category hence the water can be used for irrigational purposes with proper management. Various anthropogenic activities such as intense agricultural and aquaculture practices, aquaculture waste discharges without treatment, etc. are also the probable causes of deterioration of the quality of water. This research database provides baseline information that may be used for detecting significant trends more precisely with the help of modern tools like the Geographic Information System.

\section{Declarations}

\section{Conflicts of interest}

The author declares that there is no conflict of Interest

\section{Data Availability Statement}

All data generated or analysed during this study are included in this article.

\section{Acknowledgements}

The author is grateful to University Grants Commission, New Delhi for funding provided towards the present work in the form of PostDoctoral Fellowship for women (F.No.15-1/2013-14/PDFWM-2013-14-GE-AND-19638 (SAII) Dated 18-Apr-2014).

\section{References}

1. Alfarrah N, Walraevens K (2018) Groundwater overexploitation and seawater intrusion in coastal areas of arid and semi-arid regions. Water 10:143. https://doi.org/10.3390/w10020143

2. Aly AA, Al-Omran AM, Alharby MM (2014) The water quality index and hydrochemical characterization of groundwater resources in Hafar Albatin. Saudi Arabia. Arab J Geosci 8:4177-4190. https://doi.org/10.1007/s12517-014-1463-2

3. APHA (1998) Standard methods for the examination of water and wastewater.American Public Health Association, Washington

4. Belkhiri L, Boudoukha A, Mouni L, Baouz T (2010) Application of multivariate statistical methods and inverse geochemical modeling for characterization of groundwater - A case study: Ain Azel plain (Algeria). Geoderma 159(3-4):390-398.

https://doi.org/10.1016/j.geoderma.2010.08

5. BIS (2012) Drinking water-specification. Bureau of Indian standards, New Delhi IS: 10500: Vol. Second rev

6. Blake S, Henry T, Murray J, Flood R, Muller MR, Jones AG, Rath V (2016) Compositional multivariate statistical analysis of thermal groundwater provenance: a hydrogeochemical case study from Ireland. Appl Geochem 75:171-188

7. Brindha K, Kavitha R (2015) Hydrochemical assessment of surface water and groundwater quality along Uyyakondan channel, South India. Environ Earth Sci 73(9):5383-5393 
8. CGWB (2014) Central Ground Water Board Report on status of ground water quality in coastal aquifers of India. Ministry of Water Resources. India, Faridabad, Govt. of

9. CGWB (2017) Groundwater year book of Andhra Pradesh. Central Ground Water Board, Ministry of Water Resources, Government of India, New Delhi

10. Desai BI, Gupta SK, Shah MV, Sharma SC (1979) Hydrochemical evidence of sea water intrusion along the Mangrol-Chorwad coast of Saurashtra, Gujarat. Hydrol Sci J 24(1):71-82. DOI:10.1080/02626667909491835

11. Diana AS, Madhuri SR, Tirumalesh K (2017) Evaluation of groundwater quality and suitability for irrigation and drinking purposes in southwest Punjab, India using hydrochemical approach. Applied Water Science 7:3137-3150. D0I 10.1007/s13201-016-0456-6

12. Doneen LD (1964) Notes on Water Quality in Agriculture.Published as a Water Science and Engineering, Paper 4001, Department of Water Sciences and Engineering, University of California, Davis

13. Dudeja D, Kumar Bartarya S, Biyani AK (2011) Hydrochemical and water quality assessment of groundwater in Doon Valley of Outer Himalaya Uttarakhand India. Environ Monit Assess 181:183-204. https://doi.org/10.1007/s10661-010-1823-1827

14. Gibbs RJ (1970) Mechanisms Controlling World Water Chemistry. Science 170(3962):1088-1090. DOI:10.1126/science.170.3962.1088

15. Gibrilla EA, Bam KP, Adomako D, Ganyaglo S, Osae S, Akiti TT, Kebede S, Achoribo E, Ahialey E, Ayanu G, Agyeman EK (2011) Application of Water Quality Index (WQI) and Multivariate Analysis for Groundwater Quality Assessment of the Birimian and Cape Coast Granitoid Complex: Densu River Basin of Ghana. Water Quality Exposure Health 3:63. https://doi.org/10.1007/s12403-011-0044-0049

16. Gleeson GF, Tom (2012) Vulnerability of coastal aquifers to groundwater use and climate change. Nature Climate Change 2:342-345. https://doi.org/10.1038/nclimate1413

17. Guggenmos MR, Daughney CJ, Jackson BM, Morgenstern U (2011) Regional-scale identification of groundwater-surface water interaction using hydrochemistry and multivariate statistical methods, Wairarapa Valley, New Zealand. Hydrol Earth Syst Sci 15:33833398. https://doi.org/10.5194/hess-15-3383-20

18. Güler C, Kurt MA, Alpaslan M, Akbulut C (2012) Assessment of the impact of anthropogenic activities on the groundwater hydrology and chemistry in Tarsus coastal plain (Mersin, SE Turkey) using fuzzy clustering, multivariate statistics and GIS techniques. J Hydrol 414:435-451

19. Gulgundi MS, Shetty A (2018) Groundwater quality assessment of urban Bengaluru using multivariate statistical techniques. Applied Water Science 8:43. https://doi.org/10.1007/s13201-018-0684-z

20. He X, Wu J, He S (2019) Hydrochemical characteristics and quality evaluation of groundwater in terms of health risks in Luohe aquifer in Wuqi County of the Chinese Loess Plateau, northwest China. Human Ecological Risk Assessment: International Journal 25(1-2):32-51. https://doi.org/10.1080/10807039.2018.1531693

21. Hem JD (1985) Study and interpretation of the chemical characteristics of natural water.2254, USGS water supply paper

22. Herman B (1978) Groundwater Hydrology.New York, N.Y.: McGraw-Hill. New York, N.Y.: McGraw-Hill

23. Houatmia F, Azouzi R, Charef A, Bedir M (2016) Assessment of groundwater quality for irrigation and drinking purposes and identification of hydrogeochemical mechanisms evolution in Northeastern, Tunisia. Environ Earth Sci 75:746.

https://doi.org/10.1007/s12665-016-5441-5448

24. Iscen CF, Emiroglu Ö, Ilhan S, Arslan N, Yilmaz V, Ahiska S (2008) Application of multivariate statistical techniques in the assessment of surface water quality in Uluabat Lake, Turkey. Environ Monit Assess 144:269-276. ttps://doi.org/10.1007/s10661-007-9989-3

25. Jalali M (2007) Salinization of groundwater in arid and semi-arid zones: an example from Tajarak, western Iran. Environ Geol 52:11331149

26. Jeen SW, Kim JM, Ko KS, Yum B, Chang HW (2001) Hydrogeochemical characteristics of groundwater in a mid-western coastal aquifer system, Korea. GeoSciences Journal 5(4):339-348

27. Jiang Y, Wu Y., Groves C., Yuan D, Pat Kambesis (2009) Natural and anthropogenic factors affecting the groundwater quality in the Nandong karst underground river system in Yunan, China. J Contam Hydrol 109(1-4):49-61. https://doi.org/10.1016/j.jconhyd.2009.08.0

28. Juahir H, Zain SM, Yusoff MK, Hanidza TT, Armi AM, Toriman ME, Mokhtar M (2011) Spatial water quality assessment of Langat River basin (Malaysia) using environmetric techniques. Environ Monit Assess 173(1-4):625-641

29. Kelley WP (1951) Alkali Soils, Their Formation, Properties, and Reclamation. Reinhold Publishing Corporation. A. C. S. Monograph Series, New York, No. 111

30. Khelif S, Boudoukha A (2018) Multivariate statistical characterization of groundwater quality in Fesdis, East of Algeria. Journal of Water Land Development 37(1):65-74. DOI:10.2478/jwld-2018-0026

Page $7 / 24$ 
31. Lee JY, Cheon JY, Lee KK, Lee SY, Lee MH (2001) Statistical Evaluation of Geochemical Parameter Distribution in a Ground Water System Contaminated with Petroleum Hydrocarbons. J Environ Qual 30(5):1548-1562. https://doi.org/10.2134/jeq2001.3051548x

32. Li P, Wu J, Hui Q (2016) Hydrochemical appraisal of groundwater quality for drinking and irrigation purposes and the major influencing factors: A case study in and around Hua County, China. Arab J Geosci 9:15. https://doi.org/10.1007/s12517-015-2059-1

33. Loh YSA, Akurugu BA, Manu E, Aliou A (2020) Assessment of groundwater quality and the main controls on its hydrochemistry in some voltaian and basement aquifers, northern Ghana. Groundwater for Sustainable Development.

10.https://doi.org/10.1016/j.gsd.2019.100296

34. Machiwal D, Jha MK (2010) Tools and Techniques for Water Quality Interpretation (A. Krantzberg, G., Tanik, A., Antunes do Carmo, J.S., Indarto, A. and Ekdal (ed.); Advances i, pp. 211-252). Scientific Research Publishing, Inc., California

35. Mohapatra PK, Vijay R, Pujari PR, Sundaray SK, Mohanty BP (2011) Determination of processes affecting groundwater quality in the coastal aquifer beneath Puri city. India: a multivariate statistical approach. Water Science Technology 64:809-817. https://doi.org/10.2166/wst.2011.605

36. Paul R, Brindha K, Gowrisankar G, Tan ML, Singh MK (2019) Identification of hydrogeochemical processes controlling groundwater quality in Tripura, Northeast India using evaluation indices, GIS, and multivariate statistical methods. Environ Earth Sci 78(15):470. https://doi.org/10.1007/s12665-019-8479-6

37. Piper AM (1944) A graphic procedure in the geochemical interpretation of water-analyses. Transactions American Geophysical Union 25(6):914-928. http://dx.doi.org/10.1029/TR025i006p00914

38. Raju DSN, Ravindran CN, Mishra PK, Chidambaram L, Saxena RK (1994) Stratigraphy and Paleoenvironments of the Godavari clay in the Krishna-Godavari basin, India. Indian Journal of Petroleum Geology 3(2):33-43

39. Ramakrishna (1998) Groundwater handbook. India

40. Ramesh NR (2008) Quaternary Geology of the Deltas of Andhra Pradesh. J Geol Soc India 72:438-439

41. Ravikumar P, Somashekar RK (2017) Principal component analysis and hydrochemical facies characterization to evaluate groundwater quality in Varahi river basin, Karnataka state, India. Applied Water Science 7(2):745-755. https://doi.org/10.1007/s13201-015-0287-x

42. Reddy AGS (2013) Evaluation of hydrogeochemical characteristics of phreatic alluvial aquifers in southeastern coastal belt of Prakasam district, South India. Environ Earth Sci 68:471-485

43. Richards LA (1954) Diagnosis and improvement of saline and alkali soils.United States Department of Agriculture,Agriculture Handbook No. 60

44. Sahu P, Sikdar PK (2008) Hydrochemical framework of the aquifer in and around East Kolkata Wetlands, West Bengal, India. Environ Geol 55(4):823-835

45. Sajil Kumar PJ (2016) Deciphering the groundwater-saline water interaction in a complex coastal aquifer in South India using statistical and hydrochemical mixing models. Modeling Earth Systems Environment 2:194, 1-11

46. Sandeep R, Baldev S, Deswal S (2020) Groundwater Quality Analysis of Northeastern Haryana using Multivariate Statistical Techniques. $\mathrm{J}$ Geol Soc India 95:407-416

47. Sarikhani R, Dehnavi AG, Ahmadnejad Z, Kalantari N (2015) Hydrochemical characteristics and groundwater quality assessment in Bushehr Province, SW Iran. Environ Earth Sci 74:6265-6281

48. Sayad L, Djabri L, Bouhsina S, Bertrand C, Hani A, Chaffai H (2017) Hydrochemical study of Drean-Annaba aquifer system (NE Algeria). Journal of Water Land Development 34:259-263. DOI 10.1515/jwld-2017-0061

49. Scanlon BR, Jolly I, Sophocleous M, Zhang L (2007) Global impacts of conversions from natural to agriculturalecosystems on water resources: Quantity versus quality. Water Resour Res 43(W03437):1-20. doi:10.1029/2006WR005486

50. Shindo J, Okamoto K, Hiroyuki K (2006) Prediction of the environmental effects of excess nitrogen caused by increasing food demand with rapid economic growth in eastern Asian countries, 1961-2020. Ecol Model 193(3-4):703-720, https://doi.org/10.1016/j.ecolmodel.2005.0

51. Simeonov V, Stratis JA, Samara C, Zachariadis G, Voutsa D, Anthemidis A, Sofoniou M, Kouimtzis T (2003) Assessment of the surface water quality in Northern Greece. Water Res 37(17):4119-4124. https://doi.org/10.1016/S0043-1354(03)00

52. Sivakarun N, Udayaganesan P, Chidambaram S, Venkatramanan S, Prasanna MV, Pradeep K, Banajarani P (2020) Factors determining the hydrogeochemical processes occurring in shallow groundwater of coastal alluvial aquifer, India. Geochemistry, 80, 125623, pp.1-16. https://doi.org/10.1016/j.chemer.2020.125623

53. Subyani AM, Al Ahmadi ME (2010) Multivariate statistical analysis of groundwater quality in Wadi Ranyah, Saudi Arabia. JAKU Earth Sci 21(2):29-46 
54. Swarna Latha P, Hema Malini B (2018) Land cover change detection analysis using remote sensing and GIS techniques: a study on part of West Godavari Delta Region, Andhra Pradesh, India. Transactions-Institute of Indian Geographers 40(2):241-247

55. Swarna Latha P, Nageswara Rao K (2012) An integrated approach to assess the quality of groundwater in a coastal aquifer of Andhra Pradesh, India. Environ Earth Sci 66(8):2143-2169

56. Todd DK, Mays LW (2005) Groundwater Hydrology, 3rd edn. Wiley, New York

57. USDA (1955) Water: The Yearbook of Agriculture. The United States Department of Agriculture

58. USGS (2001) What is Groundwater - DW, Clark, Briar DW. Open-File Report, reprinted April 2001

59. Wagh V, Panaskar D, Aamalawar ML, Lolage YP, Mukate S, Narshimma A (2018) Hydrochemical characterisation and groundwater suitability for drinking and irrigation uses in semiarid region of Nashik, Maharashtra, India. Hydrospatial Analysis 2(1):43-60

60. Wang Y, Wang P, Bai Y, Tian Z, Li J, Shao X, Mustavich Laura FM, Li LB (2013) Assessment of surface water quality via multivariate statistical techniques: a case study of the Songhua River Harbin region, China. Journal of Hydro-Environment Research 7(1):30-40,. https://doi.org/10.1016/j.jher.2012.10.003

61. Weiner ER (2000) Applications of environmental chemistry-a practical guide for environmental professionals. Lewis Publishers, New York

62. Wilcox LV (1948) The Quality of Water for Irrigation Use. US Department of Agriculture, Technical Bulletin No. 962, Washington, D.C

63. World Bank (2012) India Groundwater: a Valuable but Diminishing Resource

64. Zakaria N, Anornu G, Adomako D, Owusu-Nimo F, Abass G (2021) Evolution of groundwater hydrogeochemistry and assessment of groundwater quality in the Anayari catchment. Groundwater for Sustainable Development, 12.

https://doi.org/10.1016/j.gsd.2020.100489

\section{Tables}

Table 1. The analytical results of physico-chemical parameters of groundwater samples in the study area. 


\begin{tabular}{|c|c|c|c|c|c|c|c|c|c|c|c|c|c|c|}
\hline $\begin{array}{l}\text { Sample } \\
\text { No. }\end{array}$ & $\mathrm{pH}$ & TA & EC & TDS & TH & $\mathrm{Ca}^{2+}$ & $\mathrm{Mg}^{2+}$ & $\mathrm{Na}^{+}$ & $\mathrm{K}^{+}$ & $\mathrm{HCO}^{-}$ & $\mathrm{Cl}^{-}$ & $\mathrm{SO}_{4}{ }^{2-}$ & $\mathrm{NO}_{3}^{-}$ & Water type \\
\hline 1 & 7.8 & 2421 & 283 & 1424 & 512 & 64 & 86 & 159 & 102 & 304 & 248 & 186 & 12 & $\mathrm{Mg}-\mathrm{Na}-\mathrm{Cl}-\mathrm{HCO} 3$ \\
\hline 2 & 7.9 & 2482 & 245 & 1460 & 382 & 33 & 73 & 160 & 98 & 265 & 236 & 204 & 8 & $\mathrm{Na}-\mathrm{Mg}-\mathrm{Cl}-\mathrm{HCO} 3$ \\
\hline 3 & 7.7 & 2468 & 312 & 1452 & 306 & 32 & 55 & 316 & 84 & 265 & 436 & 42 & 22 & $\mathrm{Na}-\mathrm{Mg}-\mathrm{Cl}-\mathrm{HCO} 3$ \\
\hline 4 & 7.9 & 2460 & 284 & 1447 & 412 & 64 & 61 & 235 & 102 & 265 & 356 & 145 & 36 & $\mathrm{Na}-\mathrm{Mg}-\mathrm{Cl}-\mathrm{HCO} 3$ \\
\hline 5 & 7.8 & 2185 & 198 & 1285 & 422 & 25 & 87 & 146 & 54 & 259 & 210 & 143 & 14 & $\mathrm{Mg}-\mathrm{Na}-\mathrm{Cl}-\mathrm{HCO} 3$ \\
\hline 6 & 7.9 & 2332 & 312 & 1372 & 464 & 17 & 102 & 188 & 53 & 278 & 255 & 168 & 8 & $\mathrm{Mg}-\mathrm{Na}-\mathrm{Cl}-\mathrm{HCO} 3$ \\
\hline 7 & 8.7 & 3451 & 356 & 2030 & 688 & 56 & 133 & 236 & 112 & 466 & 364 & 188 & 9 & $\mathrm{Mg}-\mathrm{Na}-\mathrm{Cl}-\mathrm{HCO} 3$ \\
\hline 8 & 8.2 & 3222 & 306 & 1895 & 312 & 47 & 47 & 224 & 102 & 401 & 342 & 212 & 12 & $\mathrm{Na}-\mathrm{Cl}-\mathrm{HCO} 3-\mathrm{SO} 4$ \\
\hline 9 & 7.7 & 2766 & 288 & 1627 & 592 & 46 & 111 & 162 & 93 & 377 & 264 & 152 & 17 & $\mathrm{Mg}-\mathrm{Na}-\mathrm{Cl}-\mathrm{HCO} 3$ \\
\hline 10 & 8.0 & 2691 & 312 & 1583 & 618 & 46 & 122 & 146 & 87 & 409 & 248 & 132 & 29 & $\mathrm{Mg}-\mathrm{Na}-\mathrm{Cl}-\mathrm{HCO} 3$ \\
\hline 11 & 7.8 & 2587 & 278 & 1522 & 542 & 66 & 92 & 196 & 93 & 364 & 302 & 122 & 36 & $\mathrm{Na}-\mathrm{Mg}-\mathrm{Cl}-\mathrm{HCO} 3$ \\
\hline 12 & 7.6 & 2470 & 216 & 1453 & 508 & 34 & 103 & 172 & 34 & 283 & 295 & 120 & 24 & $\mathrm{Mg}-\mathrm{Na}-\mathrm{Cl}-\mathrm{HCO} 3$ \\
\hline 13 & 7.6 & 3024 & 212 & 1779 & 384 & 26 & 78 & 324 & 126 & 278 & 541 & 57 & 15 & $\mathrm{Na}-\mathrm{Mg}-\mathrm{Cl}$ \\
\hline 14 & 8.1 & 3592 & 364 & 2113 & 356 & 62 & 49 & 302 & 142 & 477 & 456 & 112 & 18 & $\mathrm{Na}-\mathrm{Cl}-\mathrm{HCO} 3$ \\
\hline 15 & 7.2 & 2202 & 292 & 1295 & 364 & 33 & 68 & 143 & 64 & 383 & 236 & 42 & 7 & $\mathrm{Na}-\mathrm{Mg}-\mathrm{Cl}-\mathrm{HCO} 3$ \\
\hline 16 & 7.6 & 2460 & 302 & 1447 & 342 & 36 & 61 & 202 & 63 & 396 & 294 & 56 & 2 & $\mathrm{Na}-\mathrm{Mg}-\mathrm{Cl}-\mathrm{HCO} 3$ \\
\hline 17 & 7.6 & 2470 & 236 & 1453 & 312 & 42 & 50 & 321 & 29 & 309 & 444 & 123 & 3 & $\mathrm{Na}-\mathrm{Mg}-\mathrm{Cl}-\mathrm{HCO} 3$ \\
\hline 18 & 8.0 & 2630 & 312 & 1547 & 338 & 26 & 66 & 181 & 103 & 409 & 312 & 33 & 16 & $\mathrm{Na}-\mathrm{Mg}-\mathrm{Cl}-\mathrm{HCO} 3$ \\
\hline 19 & 7.9 & 2853 & 232 & 1678 & 342 & 64 & 44 & 268 & 112 & 304 & 376 & 164 & 4 & $\mathrm{Na}-\mathrm{Cl}-\mathrm{HCO} 3$ \\
\hline 20 & 8.4 & 2681 & 354 & 1577 & 504 & 69 & 81 & 110 & 102 & 464 & 202 & 112 & 12 & $\mathrm{Mg}-\mathrm{Na}-\mathrm{Ca}-\mathrm{HCO} 3$ \\
\hline 21 & 7.8 & 2706 & 336 & 1592 & 456 & 42 & 85 & 98 & 103 & 440 & 156 & 156 & 19 & $\mathrm{Mg}-\mathrm{Na}-\mathrm{HCO} 3-\mathrm{Cl}$ \\
\hline 22 & 7.7 & 2577 & 292 & 1516 & 396 & 42 & 71 & 294 & 88 & 383 & 402 & 88 & 18 & $\mathrm{Na}-\mathrm{Mg}-\mathrm{Cl}-\mathrm{HCO} 3$ \\
\hline 23 & 7.9 & 3177 & 288 & 1869 & 384 & 64 & 54 & 316 & 109 & 377 & 426 & 212 & 22 & $\mathrm{Na}-\mathrm{Cl}-\mathrm{HCO} 3$ \\
\hline 24 & 7.8 & 3145 & 466 & 1850 & 493 & 26 & 104 & 326 & 32 & 610 & 554 & 113 & 33 & $\mathrm{Na}-\mathrm{Mg}-\mathrm{Cl}-\mathrm{HCO} 3$ \\
\hline 25 & 7.8 & 2729 & 387 & 1605 & 484 & 42 & 92 & 178 & 94 & 507 & 248 & 98 & 39 & $\mathrm{Na}-\mathrm{Mg}-\mathrm{HCO} 3-\mathrm{Cl}$ \\
\hline 26 & 7.7 & 3528 & 364 & 2075 & 384 & 56 & 75 & 304 & 76 & 477 & 424 & 126 & 41 & $\mathrm{Na}-\mathrm{Mg}-\mathrm{Cl}-\mathrm{HCO} 3$ \\
\hline 27 & 8.1 & 2924 & 384 & 1720 & 512 & 16 & 115 & 212 & 65 & 503 & 294 & 108 & 12 & $\mathrm{Mg}-\mathrm{Na}-\mathrm{Cl}-\mathrm{HCO} 3$ \\
\hline 28 & 7.8 & 3589 & 422 & 2111 & 632 & 24 & 139 & 306 & 104 & 553 & 464 & 88 & 6 & $\mathrm{Na}-\mathrm{Mg}$-Cl- $\mathrm{HCO} 3$ \\
\hline 29 & 7.9 & 2761 & 284 & 1624 & 256 & 25 & 47 & 201 & 93 & 372 & 312 & 126 & 5 & $\mathrm{Na}-\mathrm{Mg}-\mathrm{Cl}-\mathrm{HCO} 3$ \\
\hline 30 & 8.0 & 3055 & 364 & 1797 & 508 & 64 & 85 & 303 & 88 & 477 & 412 & 103 & 12 & $\mathrm{Na}-\mathrm{Mg}-\mathrm{Cl}-\mathrm{HCO} 3$ \\
\hline
\end{tabular}




\begin{tabular}{|c|c|c|c|c|c|c|c|c|c|c|c|c|c|c|}
\hline 31 & 8.0 & 2722 & 224 & 1601 & 325 & 22 & 66 & 223 & 106 & 293 & 412 & 58 & 8 & $\mathrm{Na}-\mathrm{Mg}-\mathrm{Cl}-\mathrm{HCO} 3$ \\
\hline 32 & 7.9 & 2754 & 218 & 1620 & 322 & 42 & 53 & 249 & 143 & 286 & 372 & 180 & 26 & $\mathrm{Na}-\mathrm{Mg}-\mathrm{Cl}-\mathrm{HCO} 3$ \\
\hline 33 & 8.1 & 2912 & 388 & 1713 & 420 & 16 & 92 & 144 & 141 & 508 & 210 & 143 & 9 & Mg-Na-K- HCO3 \\
\hline 34 & 8.0 & 3135 & 364 & 1844 & 412 & 36 & 78 & 312 & 144 & 477 & 458 & 188 & 7 & $\mathrm{Na}-\mathrm{Mg}-\mathrm{Cl}-\mathrm{HCO} 3$ \\
\hline 35 & 7.8 & 3386 & 344 & 1992 & 399 & 24 & 82 & 334 & 121 & 451 & 532 & 196 & 12 & $\mathrm{Na}-\mathrm{Mg}-\mathrm{Cl}-\mathrm{HCO} 3$ \\
\hline 36 & 7.8 & 2978 & 211 & 1752 & 404 & 16 & 88 & 223 & 124 & 276 & 391 & 227 & 8 & $\mathrm{Na}-\mathrm{Mg}-\mathrm{Cl}-\mathrm{SO} 4$ \\
\hline 37 & 7.8 & 3208 & 464 & 1887 & 538 & 64 & 92 & 148 & 115 & 608 & 223 & 103 & 5 & $\mathrm{Mg}-\mathrm{Na}-\mathrm{HCO}-\mathrm{Cl}$ \\
\hline 38 & 7.8 & 3021 & 228 & 1777 & 344 & 25 & 68 & 323 & 128 & 299 & 450 & 144 & 6 & $\mathrm{Na}-\mathrm{Mg}-\mathrm{Cl}-\mathrm{HCO} 3$ \\
\hline 39 & 7.6 & 3665 & 312 & 2156 & 444 & 62 & 36 & 263 & 113 & 366 & 584 & 87 & 14 & $\mathrm{Na}-\mathrm{Cl}-\mathrm{HCO} 3$ \\
\hline 40 & 7.9 & 2519 & 198 & 1482 & 354 & 26 & 70 & 181 & 84 & 259 & 395 & 120 & 22 & $\mathrm{Na}-\mathrm{Mg}-\mathrm{Cl}-\mathrm{HCO} 3$ \\
\hline 41 & 7.8 & 3881 & 326 & 2283 & 412 & 48 & 71 & 400 & 122 & 427 & 573 & 107 & 37 & $\mathrm{Na}-\mathrm{Mg}-\mathrm{Cl}-\mathrm{HCO} 3$ \\
\hline 42 & 7.8 & 3378 & 464 & 1987 & 398 & 46 & 69 & 323 & 98 & 608 & 456 & 126 & 5 & $\mathrm{Na}-\mathrm{Mg}-\mathrm{Cl}-\mathrm{HCO} 3$ \\
\hline 43 & 7.7 & 2978 & 346 & 1752 & 354 & 32 & 67 & 216 & 112 & 453 & 302 & 133 & 9 & $\mathrm{Na}-\mathrm{Mg}-\mathrm{Cl}-\mathrm{HCO} 3$ \\
\hline 44 & 7.6 & 3410 & 278 & 2006 & 414 & 64 & 62 & 346 & 128 & 364 & 486 & 214 & 11 & $\mathrm{Na}-\mathrm{Mg}-\mathrm{Cl}-\mathrm{HCO} 3$ \\
\hline 45 & 7.9 & 3145 & 168 & 1850 & 312 & 26 & 60 & 394 & 94 & 220 & 536 & 204 & 8 & $\mathrm{Na}-\mathrm{Mg}-\mathrm{Cl}$ \\
\hline 46 & 7.3 & 2200 & 212 & 1294 & 364 & 30 & 70 & 232 & 79 & 278 & 346 & 68 & 4 & $\mathrm{Na}-\mathrm{Mg}-\mathrm{Cl}-\mathrm{HCO} 3$ \\
\hline 47 & 7.9 & 3188 & 146 & 1875 & 414 & 22 & 87 & 406 & 142 & 191 & 584 & 178 & 22 & $\mathrm{Na}-\mathrm{Mg}-\mathrm{Cl}$ \\
\hline 48 & 7.9 & 3777 & 234 & 2222 & 424 & 18 & 92 & 402 & 124 & 307 & 574 & 96 & 38 & $\mathrm{Na}-\mathrm{Mg}-\mathrm{Cl}$ \\
\hline 49 & 7.6 & 3653 & 198 & 2149 & 519 & 32 & 107 & 414 & 97 & 259 & 602 & 212 & 4 & $\mathrm{Na}-\mathrm{Mg}-\mathrm{Cl}$ \\
\hline 50 & 7.9 & 2312 & 188 & 1360 & 164 & 46 & 12 & 312 & 80 & 246 & 428 & 83 & 4 & $\mathrm{Na}-\mathrm{Cl}-\mathrm{HCO} 3$ \\
\hline 51 & 7.7 & 2083 & 214 & 1225 & 217 & 60 & 33 & 316 & 46 & 280 & 592 & 123 & 13 & $\mathrm{Na}-\mathrm{Cl}-\mathrm{HCO} 3$ \\
\hline 52 & 8.0 & 2028 & 224 & 1193 & 248 & 22 & 47 & 173 & 86 & 293 & 243 & 86 & 6 & $\mathrm{Na}-\mathrm{Mg}-\mathrm{Cl}-\mathrm{HCO} 3$ \\
\hline 53 & 8.0 & 2038 & 188 & 1199 & 114 & 26 & 12 & 324 & 94 & 246 & 594 & 28 & 18 & $\mathrm{Na}-\mathrm{Cl}$ \\
\hline 54 & 7.9 & 1675 & 134 & 985 & 195 & 22 & 34 & 192 & 59 & 176 & 264 & 68 & 23 & $\mathrm{Na}-\mathrm{Mg}-\mathrm{Cl}-\mathrm{HCO} 3$ \\
\hline 55 & 7.9 & 1714 & 124 & 1008 & 188 & 36 & 24 & 208 & 67 & 162 & 282 & 58 & 36 & $\mathrm{Na}-\mathrm{Cl}$ \\
\hline 56 & 7.9 & 2540 & 320 & 1494 & 154 & 46 & 10 & 315 & 104 & 419 & 446 & 35 & 16 & $\mathrm{Na}-\mathrm{Cl}-\mathrm{HCO} 3$ \\
\hline 57 & 7.6 & 2185 & 202 & 1285 & 195 & 28 & 38 & 194 & 103 & 265 & 326 & 88 & 5 & $\mathrm{Na}-\mathrm{Mg}-\mathrm{Cl}-\mathrm{HCO} 3$ \\
\hline 58 & 7.9 & 2317 & 232 & 1363 & 140 & 11 & 29 & 192 & 113 & 304 & 272 & 127 & 18 & $\mathrm{Na}-\mathrm{Cl}-\mathrm{HCO} 3$ \\
\hline
\end{tabular}

Table 2. The calculated values of chemical parameters for analyzing their suitability for irrigation. 


\begin{tabular}{|c|c|c|c|c|c|c|c|}
\hline Sample No & $\mathrm{Na} \%$ & $\mathrm{Cl}^{-} / \mathrm{HCO}_{3}^{-}$ & SAR & RSC & PI & $\mathrm{KR}$ & CR \\
\hline 1 & 48.2 & 1.4 & 3.1 & -5.2 & 53.4 & 1.1 & 1.8 \\
\hline 2 & 55.4 & 1.5 & 3.6 & -3.3 & 62.0 & 1.5 & 2.1 \\
\hline 3 & 72.2 & 2.8 & 7.9 & -1.8 & 79.7 & 3.6 & 2.5 \\
\hline 4 & 60.9 & 2.3 & 5.0 & -3.9 & 66.7 & 1.9 & 2.5 \\
\hline 5 & 47.8 & 1.4 & 3.1 & -4.2 & 56.9 & 1.3 & 1.7 \\
\hline 6 & 50.7 & 1.6 & 3.8 & -4.7 & 59.1 & 1.6 & 1.9 \\
\hline 7 & 48.9 & 1.3 & 3.9 & -6.1 & 54.3 & 1.2 & 1.5 \\
\hline 8 & 66.5 & 1.5 & 5.5 & 0.3 & 77.0 & 2.4 & 1.8 \\
\hline 9 & 45.2 & 1.2 & 2.9 & -5.3 & 51.6 & 1.0 & 1.4 \\
\hline 10 & 41.0 & 1.0 & 2.6 & -5.6 & 47.8 & 0.9 & 1.2 \\
\hline 11 & 50.2 & 1.4 & 3.7 & -4.9 & 56.7 & 1.2 & 1.5 \\
\hline 12 & 45.1 & 1.8 & 3.3 & -5.5 & 54.6 & 1.3 & 1.9 \\
\hline 13 & 69.3 & 3.3 & 7.2 & -3.1 & 74.6 & 3.1 & 3.0 \\
\hline 14 & 70.2 & 1.6 & 7.0 & 0.7 & 78.7 & 2.7 & 1.6 \\
\hline 15 & 51.9 & 1.1 & 3.3 & -1.0 & 64.7 & 1.4 & 1.0 \\
\hline 16 & 60.3 & 1.3 & 4.8 & -0.3 & 72.6 & 2.1 & 1.2 \\
\hline 17 & 70.2 & 2.5 & 7.9 & -1.2 & 80.3 & 3.5 & 2.4 \\
\hline 18 & 60.9 & 1.3 & 4.3 & -0.1 & 71.5 & 2.0 & 1.2 \\
\hline 19 & 68.0 & 2.1 & 6.3 & -1.9 & 75.1 & 2.5 & 2.3 \\
\hline 20 & 42.3 & 0.7 & 2.1 & -2.5 & 50.8 & 0.7 & 0.9 \\
\hline 21 & 43.1 & 0.6 & 2.0 & -1.9 & 52.0 & 0.8 & 0.9 \\
\hline 22 & 65.5 & 1.8 & 6.4 & -1.6 & 73.9 & 2.6 & 1.7 \\
\hline 23 & 68.3 & 1.9 & 7.0 & -1.5 & 75.8 & 2.7 & 2.2 \\
\hline 24 & 60.4 & 1.6 & 6.4 & 0.1 & 72.2 & 2.5 & 1.5 \\
\hline 25 & 51.2 & 0.8 & 3.5 & -1.4 & 61.0 & 1.3 & 0.9 \\
\hline 26 & 62.8 & 1.5 & 6.2 & -1.2 & 72.2 & 2.3 & 1.5 \\
\hline 27 & 51.5 & 1.0 & 4.1 & -2.0 & 62.2 & 1.6 & 1.0 \\
\hline 28 & 55.8 & 1.4 & 5.3 & -3.6 & 62.9 & 1.9 & 1.3 \\
\hline 29 & 68.5 & 1.4 & 5.5 & 1.0 & 80.9 & 2.8 & 1.5 \\
\hline 30 & 60.3 & 1.5 & 5.9 & -2.3 & 68.5 & 2.0 & 1.4 \\
\hline 31 & 65.6 & 2.4 & 5.4 & -1.7 & 73.4 & 2.5 & 2.2 \\
\hline 32 & 69.2 & 2.2 & 6.0 & -1.7 & 75.3 & 2.6 & 2.5 \\
\hline 33 & 55.5 & 0.7 & 3.1 & -0.1 & 62.4 & 1.3 & 0.9 \\
\hline 34 & 65.8 & 1.7 & 6.7 & -0.4 & 75.1 & 2.7 & 1.8 \\
\hline 35 & 68.9 & 2.0 & 7.3 & -0.6 & 76.7 & 3.1 & 2.1 \\
\hline 36 & 61.5 & 2.4 & 4.8 & -3.5 & 66.5 & 2.1 & 2.9 \\
\hline 37 & 46.6 & 0.6 & 2.8 & -0.8 & 55.8 & 0.9 & 0.7 \\
\hline 38 & 71.6 & 2.6 & 7.6 & -2.0 & 77.7 & 3.5 & 2.6 \\
\hline
\end{tabular}




\begin{tabular}{|llllllll|}
39 & 70.2 & 2.7 & 6.6 & -0.1 & 79.3 & 2.7 & 2.5 \\
\hline 40 & 58.6 & 2.6 & 4.2 & -2.8 & 66.5 & 1.9 & 2.6 \\
\hline
\end{tabular}

\begin{tabular}{|llllllll|}
\hline 41 & 71.4 & 2.3 & 8.6 & -1.2 & 78.2 & 3.4 & 2.2 \\
\hline 42 & 67.6 & 1.3 & 7.0 & 2.0 & 78.2 & 2.8 & 1.3 \\
\hline 43 & 63.4 & 1.1 & 5.0 & 0.4 & 73.6 & 2.2 & 1.2 \\
\hline 44 & 68.9 & 2.3 & 7.4 & -2.3 & 75.0 & 2.8 & 2.5 \\
\hline 45 & 75.8 & 4.2 & 9.7 & -2.6 & 81.5 & 4.6 & 4.4 \\
\hline 46 & 62.5 & 2.1 & 5.3 & -2.7 & 70.4 & 2.3 & 2.0 \\
\hline 47 & 72.0 & 5.3 & 8.7 & -5.1 & 74.9 & 3.7 & 5.3 \\
\hline 48 & 70.9 & 3.2 & 8.5 & -3.4 & 76.0 & 3.7 & 3.0 \\
\hline 49 & 66.4 & 4.0 & 7.9 & -6.1 & 70.7 & 3.0 & 4.1 \\
\hline 50 & 82.7 & 3.0 & 10.6 & 0.8 & 92.5 & 5.4 & 2.8 \\
\hline 51 & 72.2 & 3.6 & 8.1 & -1.1 & 81.6 & 3.4 & 3.4 \\
\hline 52 & 66.2 & 1.4 & 4.8 & -0.2 & 77.9 & 2.5 & 1.5 \\
\hline 53 & 87.9 & 4.2 & 13.2 & 1.8 & 98.4 & 8.5 & 3.5 \\
\hline 54 & 71.7 & 2.6 & 6.0 & -1.0 & 82.1 & 3.4 & 2.5 \\
\hline 55 & 74.1 & 3.0 & 6.6 & -1.1 & 83.4 & 3.5 & 2.8 \\
\hline 56 & 84.2 & 1.8 & 11.0 & 3.8 & 97.3 & 5.7 & 1.6 \\
\hline 57 & 71.1 & 2.1 & 5.6 & -0.2 & 81.4 & 3.0 & 2.1 \\
\hline 58 & 79.2 & 1.5 & 6.9 & 2.0 & 93.7 & 4.8 & 1.7 \\
\hline
\end{tabular}

Table 3. Groundwater classification based on the Piper diagram. 


\begin{tabular}{|c|c|c|c|}
\hline $\begin{array}{l}\text { Sub- } \\
\text { field }\end{array}$ & Chemical characteristics & No. of samples in different fields & Total \\
\hline 1 & Alkaline earths $(\mathrm{Ca}+\mathrm{Mg})$ exceeds alkalies $(\mathrm{Na}+\mathrm{K})$ & $1,5,6,7,9,10,11,12,14,15,20,21,25,27,33,37$ & 16 \\
\hline \multirow[t]{3}{*}{2} & Alkalies exceeds alkaline earths & $2,3,4,8,13,14,16,17,18,19,22,23,24,26,28,29,30$ & 43 \\
\hline & & $31,32,34,35,36,38,39,40,41,42,43,44,45,46,47$ & \\
\hline & & $48,49,50,51,52,53,54,55,56,57,58$ & \\
\hline 3 & Weak acids $\left(\mathrm{CO}_{3}+\mathrm{HCO}_{3}\right)$ exceeds strong acids $\left(\mathrm{SO}_{4}+\mathrm{Cl}\right)$ & $9,14,15,20,21,25,27,33,37$ & \\
\hline \multirow[t]{3}{*}{4} & Strong acids exceeds weak acids & $1,2,3,4,5,6,7,8,10,11,12,13,14,16,17,18,19,22$ & 49 \\
\hline & & $23,24,26,28,29,30,31,32,34,35,36,38,39,40$ & \\
\hline & & $41,42,43,44,45,46,47,48,49,50,51,52,53,54,55,56,57,58$ & \\
\hline 5 & Carbonate hardness (secondary alkalinity) exceeds $50 \%$ & - nil- & - \\
\hline 6 & $\begin{array}{l}\text { Non-carbonate hardness (secondary alkalinity) exceeds } \\
50 \%\end{array}$ & - nil- & - \\
\hline \multirow[t]{3}{*}{7} & Non-carbonate alkali (primary salinity) exceeds $50 \%$ & $2,3,4,8,13,14,16,17,18,19,22,23,24,26,28,29,30$ & 43 \\
\hline & & $31,32,34,35,36,38,39,40,41,42,43,44$ & \\
\hline & & $45,46,47,48,49,50,51,52,53,54,55,56,57,58$ & \\
\hline 8 & Carbonate alkali (primary salinity) exceeds $50 \%$ & - nil- & - \\
\hline 9 & None of the cation or anion pairs exceed $50 \%$ & $1,5,6,7,9,10,11,12,14,15,20,21,25,27,33,37$ & 16 \\
\hline
\end{tabular}

Table 4. The range of concentrations of chemical constituents in groundwater and their effect on human health. 


\begin{tabular}{|c|c|c|c|c|c|c|c|c|c|c|}
\hline \multirow[t]{2}{*}{ Parameter } & \multicolumn{2}{|c|}{$\begin{array}{l}\text { Bureau of Indian } \\
\text { Standards (2012) }\end{array}$} & \multirow[t]{2}{*}{ Min } & \multirow[t]{2}{*}{ Max } & \multirow[t]{2}{*}{ Mean } & \multirow[t]{2}{*}{ Std } & \multirow[t]{2}{*}{ CV } & \multicolumn{2}{|c|}{$\begin{array}{l}\text { Groundwater } \\
\text { samples exceeds the } \\
\text { desirable limit }\end{array}$} & \multirow[t]{2}{*}{ Effect on human health } \\
\hline & $\begin{array}{l}\text { Desirable } \\
\text { limit }\end{array}$ & $\begin{array}{l}\text { Permissible } \\
\text { limit }\end{array}$ & & & & & & $\begin{array}{l}\text { No of } \\
\text { Samples }\end{array}$ & $\begin{array}{l}\% \text { of } \\
\text { Samples }\end{array}$ & \\
\hline $\mathrm{pH}$ & $6.5-8.5$ & - & 7.2 & 8.7 & 7.8 & 0.2 & 0.03 & 1 & 1.7 & Bitter taste \\
\hline $\begin{array}{l}\mathrm{EC} \\
(\mu \mathrm{S} / \mathrm{cm})\end{array}$ & NR & NR & 1675 & 3881 & 2800.7 & 517.4 & 0.18 & - & - & - \\
\hline $\mathrm{TA}(\mathrm{mg} / \mathrm{L})$ & 200 & 600 & 124 & 466 & 283.3 & 81.1 & 0.29 & 49 & 84.5 & $\begin{array}{l}\text { Gastrointestinal issues, } \\
\text { Nausea and skin irritations }\end{array}$ \\
\hline $\begin{array}{l}\text { TDS } \\
(\mathrm{mg} / \mathrm{L})\end{array}$ & 500 & 2000 & 985 & 2283 & 1647.4 & 304.4 & 0.18 & 58 & 100.0 & $\begin{array}{l}\text { Salty and bitter taste, lung } \\
\text { irritation, rashes, vomiting, } \\
\text { dizziness }\end{array}$ \\
\hline $\begin{array}{l}\text { TH } \\
(\mathrm{mg} / \mathrm{L})\end{array}$ & 300 & 600 & 114 & 688 & 386.1 & 123.8 & 0.32 & 48 & 82.8 & $\begin{array}{l}\text { Cardiovascular problems, } \\
\text { diabetes, neural diseases, } \\
\text { and renal dysfunction }\end{array}$ \\
\hline $\begin{array}{l}\mathrm{Ca}^{2+} \\
(\mathrm{mg} / \mathrm{L})\end{array}$ & 75 & 200 & 11 & 69 & 38.6 & 16.3 & 0.42 & - & - & $\begin{array}{l}\text { Hypercalcaemia and renal } \\
\text { insufficiency }\end{array}$ \\
\hline $\begin{array}{l}\mathrm{Mg}^{2+} \\
(\mathrm{mg} / \mathrm{L})\end{array}$ & 30 & 100 & 10 & 139 & 70.4 & 28.6 & 0.41 & 53 & 91.4 & $\begin{array}{l}\text { Hypermagnesaemia, } \\
\text { diarrhea, etc. }\end{array}$ \\
\hline $\begin{array}{l}\mathrm{Na}^{+} \\
(\mathrm{mg} / \mathrm{L})\end{array}$ & NR & NR & 98 & 414 & 249.8 & 81.2 & 0.32 & - & - & - \\
\hline $\mathrm{K}^{+}(\mathrm{mg} / \mathrm{L})$ & NR & NR & 29 & 143 & 95.6 & 27.8 & 0.29 & - & - & - \\
\hline $\begin{array}{l}\mathrm{HCO}_{3}^{-} \\
(\mathrm{mg} / \mathrm{L})\end{array}$ & NR & $N R$ & 162 & 610 & 361.7 & 109.1 & 0.30 & - & - & - \\
\hline $\mathrm{Cl}^{-}(\mathrm{mg} / \mathrm{L})$ & 250 & 1000 & 156 & 602 & 380.0 & 121.3 & 0.32 & 47 & 81.0 & Congestive heart failure \\
\hline $\begin{array}{l}\mathrm{SO}_{4}{ }^{2-} \\
(\mathrm{mg} / \mathrm{L})\end{array}$ & 200 & 400 & 28 & 227 & 124.3 & 52.5 & 0.42 & 7 & 12.1 & $\begin{array}{l}\text { Bitter taste and laxative } \\
\text { effect }\end{array}$ \\
\hline $\begin{array}{l}\mathrm{NO}_{3}^{-} \\
(\mathrm{mg} / \mathrm{L})\end{array}$ & 45 & NR & 2 & 41 & 15.6 & 10.7 & 0.68 & - & - & Blue baby syndrome \\
\hline
\end{tabular}

Table 5. Classification of groundwater based on Wilcox (1948) diagram.

\begin{tabular}{|c|c|c|c|}
\hline Category & Sample numbers & $\begin{array}{l}\text { Number } \\
\text { of } \\
\text { samples }\end{array}$ & $\begin{array}{l}\text { Percentage } \\
\text { of samples }\end{array}$ \\
\hline $\begin{array}{l}\text { Permissible } \\
\text { to doubtful }\end{array}$ & 54,55 & 2 & 3.4 \\
\hline $\begin{array}{l}\text { Doubtful to } \\
\text { unsuitable }\end{array}$ & $1,2,3,4,5,6,9,10,11,12,15,16,17,18,19,20,21,22,25,27,29,31,32,33,36,40,43,46,50,51,52,53,56,57,58$ & 35 & 60.3 \\
\hline Unsuitable & $7,8,13,14,23,24,26,28,30,34,35,37,38,39,41,42,44,45,47,48,49$ & 21 & 36.2 \\
\hline
\end{tabular}

Table 6. Classification of groundwater based on USSL diagram (USDA 1955) 


\begin{tabular}{|llll|}
\hline Classification & Sample numbers & $\begin{array}{l}\text { Number of } \\
\text { samples }\end{array}$ & $\begin{array}{l}\text { Percentage of } \\
\text { samples }\end{array}$ \\
\hline C3S1 & 5,15 & 2 & 3.4 \\
\hline C3S2 & $46,51,52,54,55,57$ & 6 & 10.3 \\
\hline C3S3 & 53 & 1 & 1.7 \\
\hline C4S1 & $1,2,6,9,10,12,20,21,25,33,37$ & 11 & 19.0 \\
\hline C4S2 & $3,4,7,8,11,13,14,16,17,18,19,22,23,24,26,27,28,29,30,31,32,34,35,36,38,39,40,42,43,44,58$ & 31 & 53.4 \\
\hline C4S3 & $41,45,47,48,49,50,56$ & 7 & 12.1 \\
\hline
\end{tabular}

Table 7. The results of principal components and factors of groundwater samples

\begin{tabular}{|c|c|c|c|c|c|c|c|c|c|c|c|c|}
\hline & $\mathrm{F} 1$ & F2 & F3 & F4 & F5 & F6 & F7 & F8 & F9 & F10 & F11 & F12 \\
\hline Eigenvalue & 4.332 & 2.659 & 1.407 & 1.262 & 1.092 & 0.896 & 0.651 & 0.424 & 0.157 & 0.070 & 0.038 & 0.010 \\
\hline $\begin{array}{l}\text { Variability } \\
(\%)\end{array}$ & 33.323 & 20.456 & 10.825 & 9.711 & 8.397 & 6.891 & 5.011 & 3.264 & 1.210 & 0.540 & 0.291 & 0.080 \\
\hline $\begin{array}{l}\text { Cumulative } \\
\%\end{array}$ & 33.323 & 53.779 & 64.605 & 74.316 & 82.714 & 89.604 & 94.615 & 97.879 & 99.089 & 99.629 & 99.920 & 100 \\
\hline Variable & F1 & F2 & F3 & F4 & F5 & F6 & F7 & F8 & F9 & F10 & F11 & F12 \\
\hline $\mathrm{pH}$ & 0.262 & -0.205 & 0.433 & -0.518 & 0.074 & -0.370 & -0.523 & -0.131 & 0.026 & -0.002 & -0.002 & 0.000 \\
\hline TA & 0.706 & -0.426 & -0.431 & -0.172 & -0.214 & -0.036 & -0.057 & 0.157 & -0.114 & 0.009 & -0.131 & -0.013 \\
\hline EC & 0.917 & 0.332 & 0.008 & 0.017 & -0.055 & -0.036 & 0.077 & 0.024 & 0.195 & -0.011 & -0.009 & -0.006 \\
\hline TDS & 0.917 & 0.332 & 0.008 & 0.017 & -0.055 & -0.036 & 0.077 & 0.024 & 0.195 & -0.011 & -0.009 & -0.006 \\
\hline TH & 0.734 & -0.452 & 0.106 & 0.335 & 0.227 & 0.107 & 0.024 & -0.250 & -0.031 & 0.024 & -0.027 & 0.069 \\
\hline $\mathrm{Ca}^{2+}$ & 0.312 & -0.085 & -0.137 & -0.543 & 0.347 & 0.653 & 0.018 & -0.182 & -0.006 & -0.016 & 0.014 & -0.024 \\
\hline $\mathrm{Mg}^{2+}$ & 0.634 & -0.452 & 0.154 & 0.547 & 0.136 & -0.118 & -0.019 & -0.152 & -0.087 & -0.028 & 0.034 & -0.064 \\
\hline $\mathrm{Na}^{+}$ & 0.301 & 0.878 & -0.166 & 0.124 & 0.034 & 0.021 & -0.211 & -0.021 & -0.134 & -0.178 & 0.000 & 0.015 \\
\hline $\mathrm{K}^{+}$ & 0.427 & 0.316 & 0.419 & -0.415 & -0.155 & -0.245 & 0.499 & -0.117 & -0.156 & 0.004 & 0.004 & 0.001 \\
\hline $\mathrm{HCO}_{3}{ }^{-}$ & 0.717 & -0.390 & -0.430 & -0.182 & -0.252 & -0.061 & -0.051 & 0.155 & -0.058 & 0.012 & 0.135 & 0.019 \\
\hline $\mathrm{Cl}^{-}$ & 0.275 & 0.878 & -0.208 & 0.126 & 0.039 & 0.012 & -0.194 & -0.105 & -0.089 & 0.188 & 0.006 & -0.009 \\
\hline $\mathrm{SO}_{4}^{-}$ & 0.422 & 0.063 & 0.705 & 0.105 & 0.068 & 0.347 & -0.104 & 0.410 & -0.071 & 0.027 & 0.004 & 0.004 \\
\hline $\mathrm{NO}_{3}{ }^{-}$ & 0.079 & 0.042 & -0.230 & -0.098 & 0.866 & -0.344 & 0.129 & 0.213 & -0.011 & 0.006 & 0.002 & 0.002 \\
\hline
\end{tabular}

Table 8. Correlation matrix of different parameters of groundwater samples 


\begin{tabular}{|c|c|c|c|c|c|c|c|c|c|c|c|c|c|}
\hline Variable & $p H$ & $T A$ & $E C$ & $T D S$ & $T H$ & $\mathrm{Ca}^{2+}$ & $\mathrm{Mg}^{2+}$ & $\mathrm{Na}^{+}$ & $\mathrm{K}^{+}$ & $\mathrm{HCO}_{3}^{-}$ & $\mathrm{Cl}^{-}$ & $\mathrm{SO}_{4}^{-}$ & $\mathrm{NO}_{3}$ \\
\hline $\mathrm{pH}$ & 1 & & & & & & & & & & & & \\
\hline TA & 0.179 & 1 & & & & & & & & & & & \\
\hline EC & 0.137 & 0.490 & 1 & & & & & & & & & & \\
\hline TDS & 0.137 & 0.490 & 1 & 1 & & & & & & & & & \\
\hline TH & 0.154 & 0.520 & 0.502 & 0.502 & 1 & & & & & & & & \\
\hline $\mathrm{Ca}^{2+}$ & 0.119 & 0.280 & 0.200 & 0.200 & 0.263 & 1 & & & & & & & \\
\hline $\mathrm{Mg}^{2+}$ & 0.123 & 0.438 & 0.417 & 0.417 & 0.923 & -0.082 & 1 & & & & & & \\
\hline $\mathrm{Na}^{+}$ & -0.133 & -0.097 & 0.525 & 0.525 & -0.141 & 0.004 & -0.139 & 1 & & & & & \\
\hline $\mathrm{K}^{+}$ & 0.272 & 0.070 & 0.514 & 0.514 & 0.061 & 0.092 & -0.005 & 0.192 & 1 & & & & \\
\hline $\mathrm{HCO}_{3}{ }^{-}$ & 0.185 & 0.961 & 0.524 & 0.524 & 0.491 & 0.260 & 0.423 & -0.074 & 0.098 & 1 & & & \\
\hline $\mathrm{Cl}^{-}$ & -0.152 & -0.115 & 0.505 & 0.505 & -0.137 & 0.006 & -0.159 & 0.926 & 0.177 & -0.088 & 1 & & \\
\hline $\mathrm{SO}_{4}^{-}$ & 0.224 & 0.001 & 0.387 & 0.387 & 0.343 & 0.147 & 0.319 & 0.107 & 0.267 & -0.009 & 0.033 & 1 & \\
\hline $\mathrm{NO}_{3}{ }^{-}$ & 0.059 & 0.008 & 0.060 & 0.060 & 0.092 & 0.145 & 0.065 & 0.077 & -0.017 & -0.013 & 0.078 & -0.122 & 1 \\
\hline
\end{tabular}

Figures 

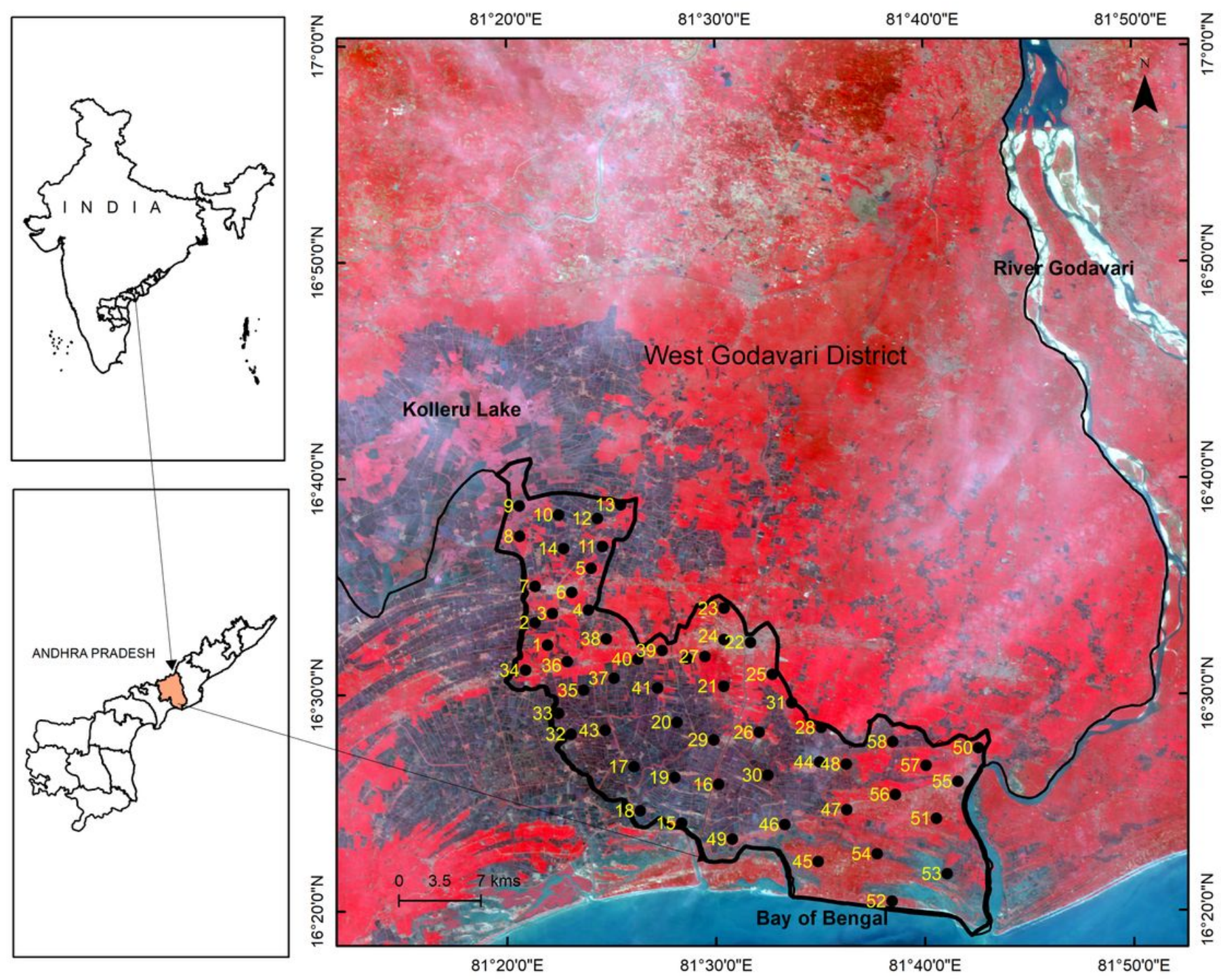

Figure 1

Location map of the study area. Note: The designations employed and the presentation of the material on this map do not imply the expression of any opinion whatsoever on the part of Research Square concerning the legal status of any country, territory, city or area or of its authorities, or concerning the delimitation of its frontiers or boundaries. This map has been provided by the authors. 

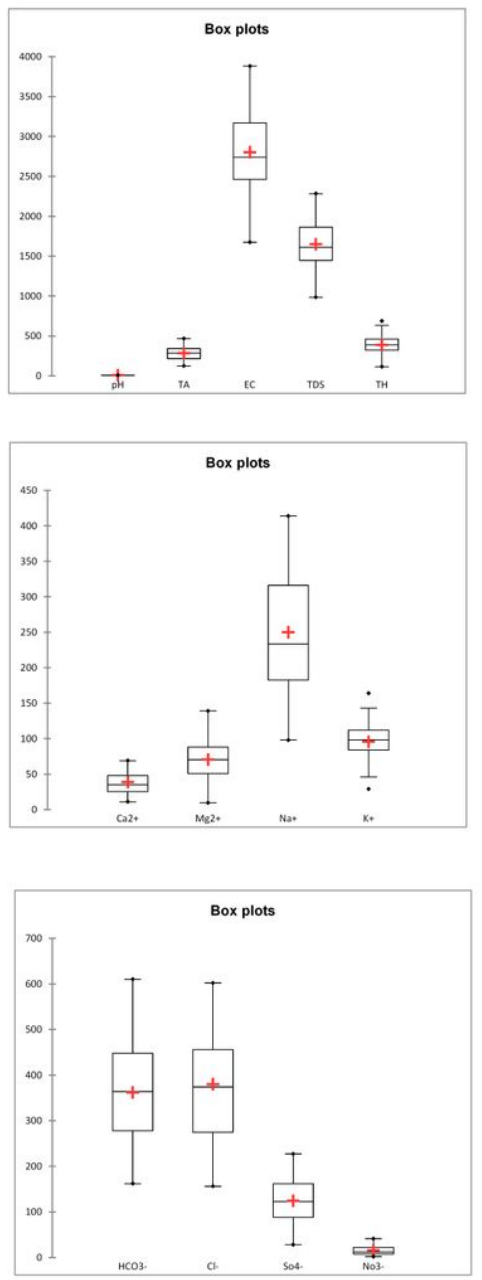

Figure 2

Geomorphology of the study area. 


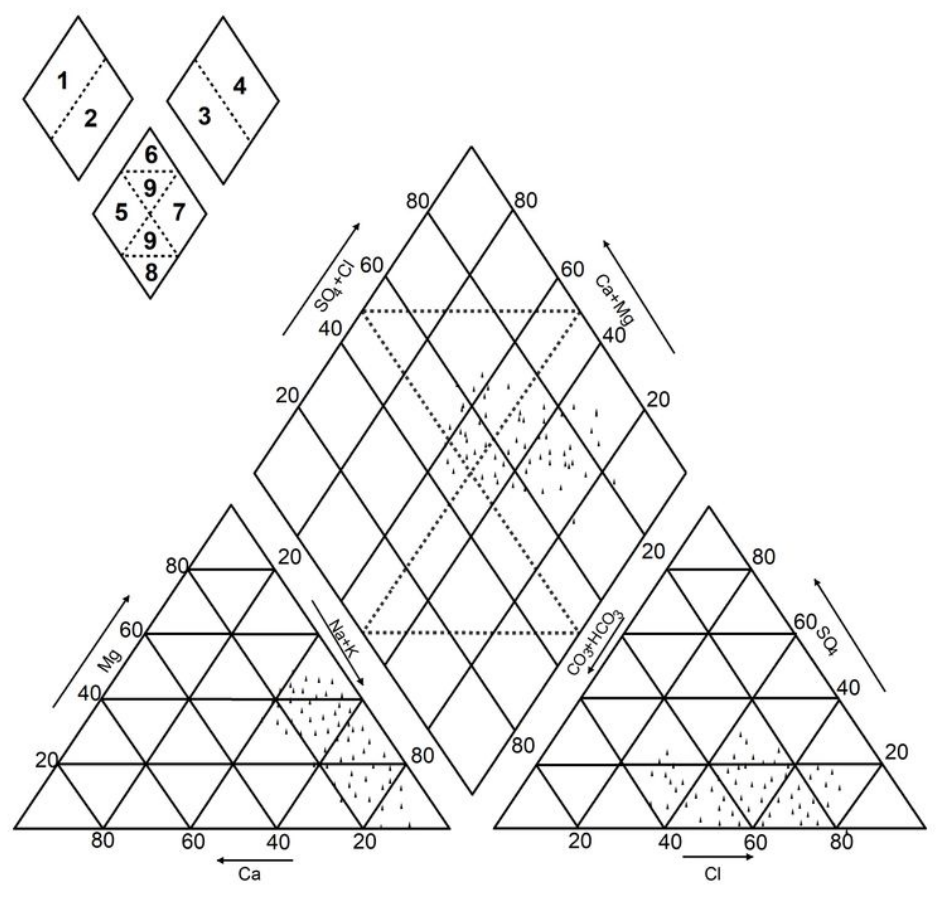

Figure 3

Data normality of water quality parameters explaining by the Box plot 

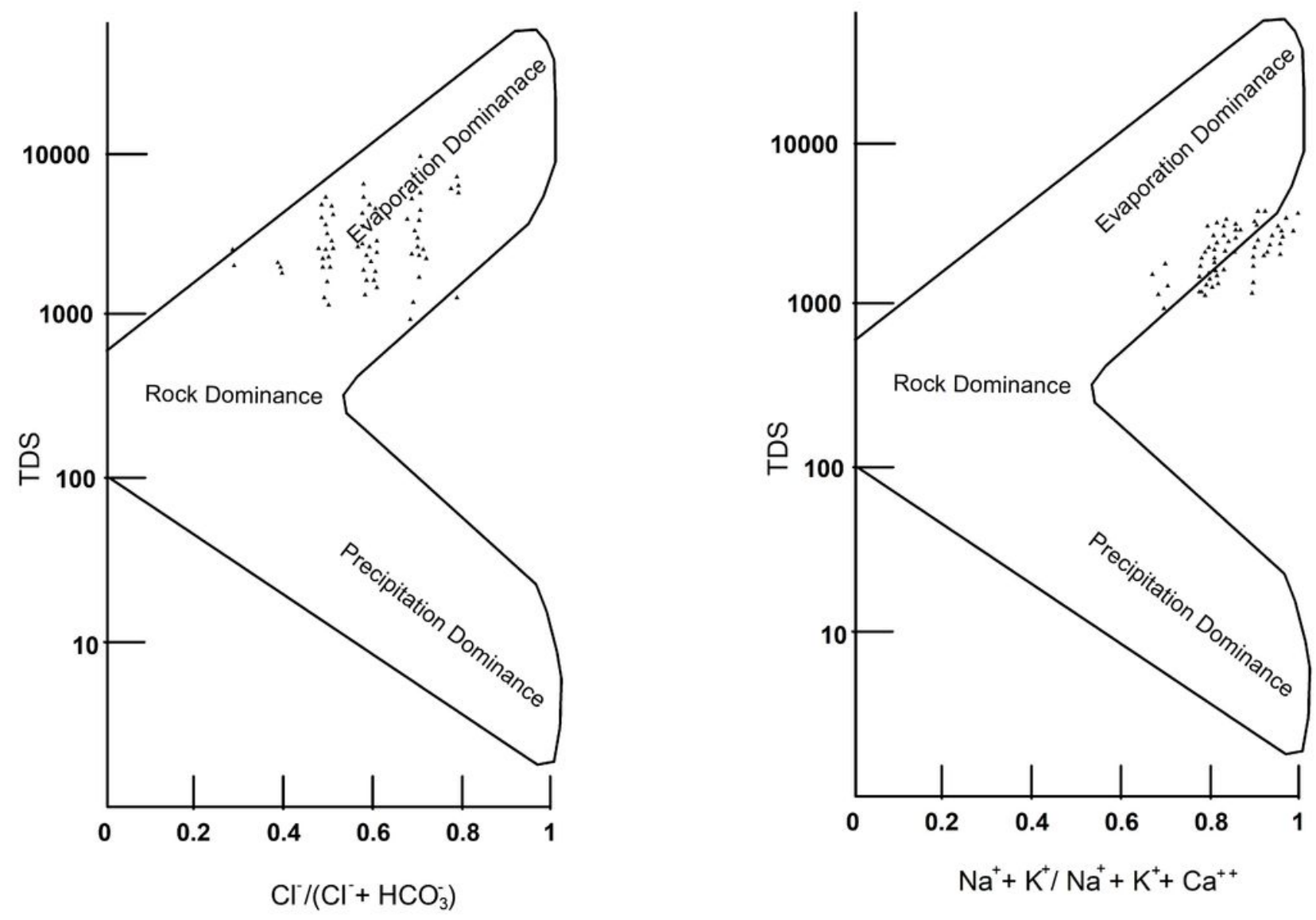

Figure 4

Classification of hydrochemical facies using the Piper plot. 


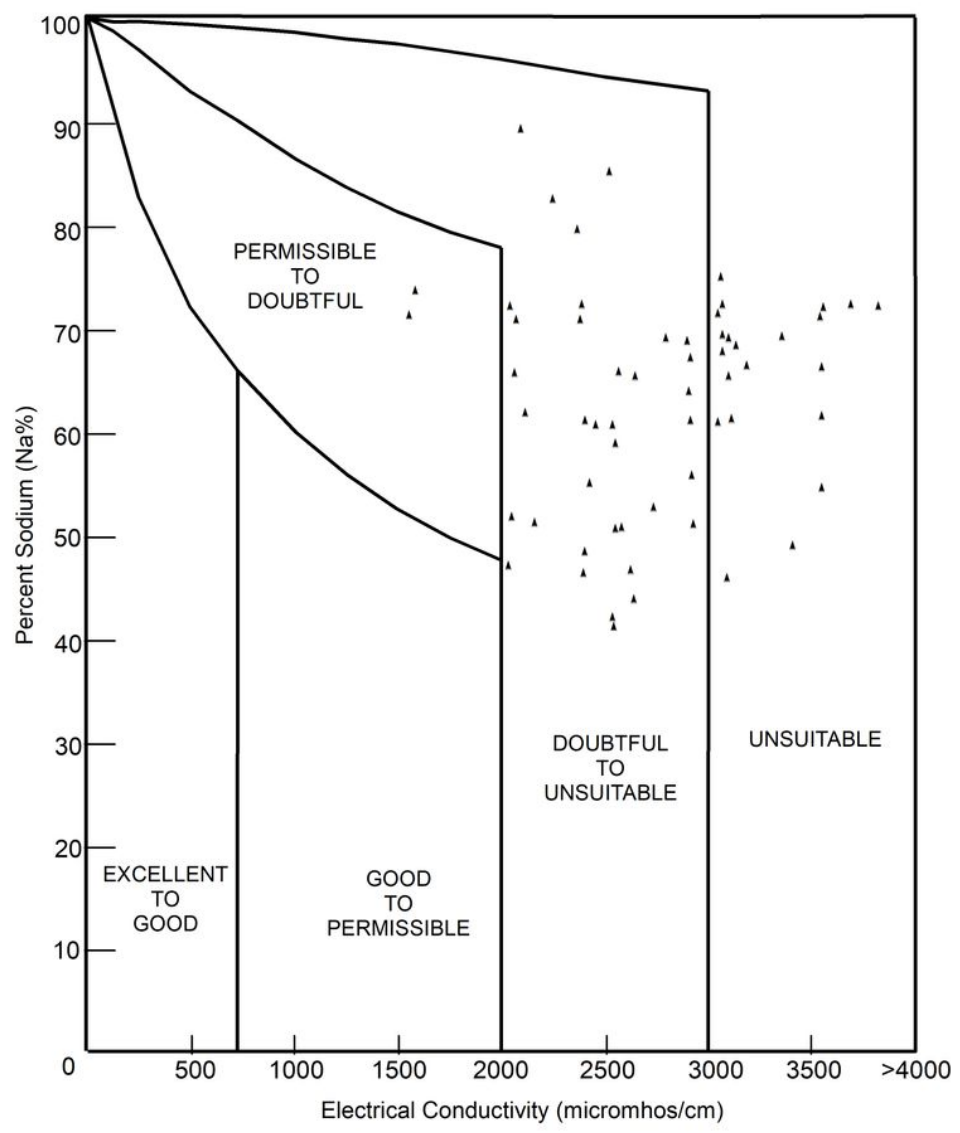

Figure 5

Gibbs plot showing the geochemical process of groundwaters. 


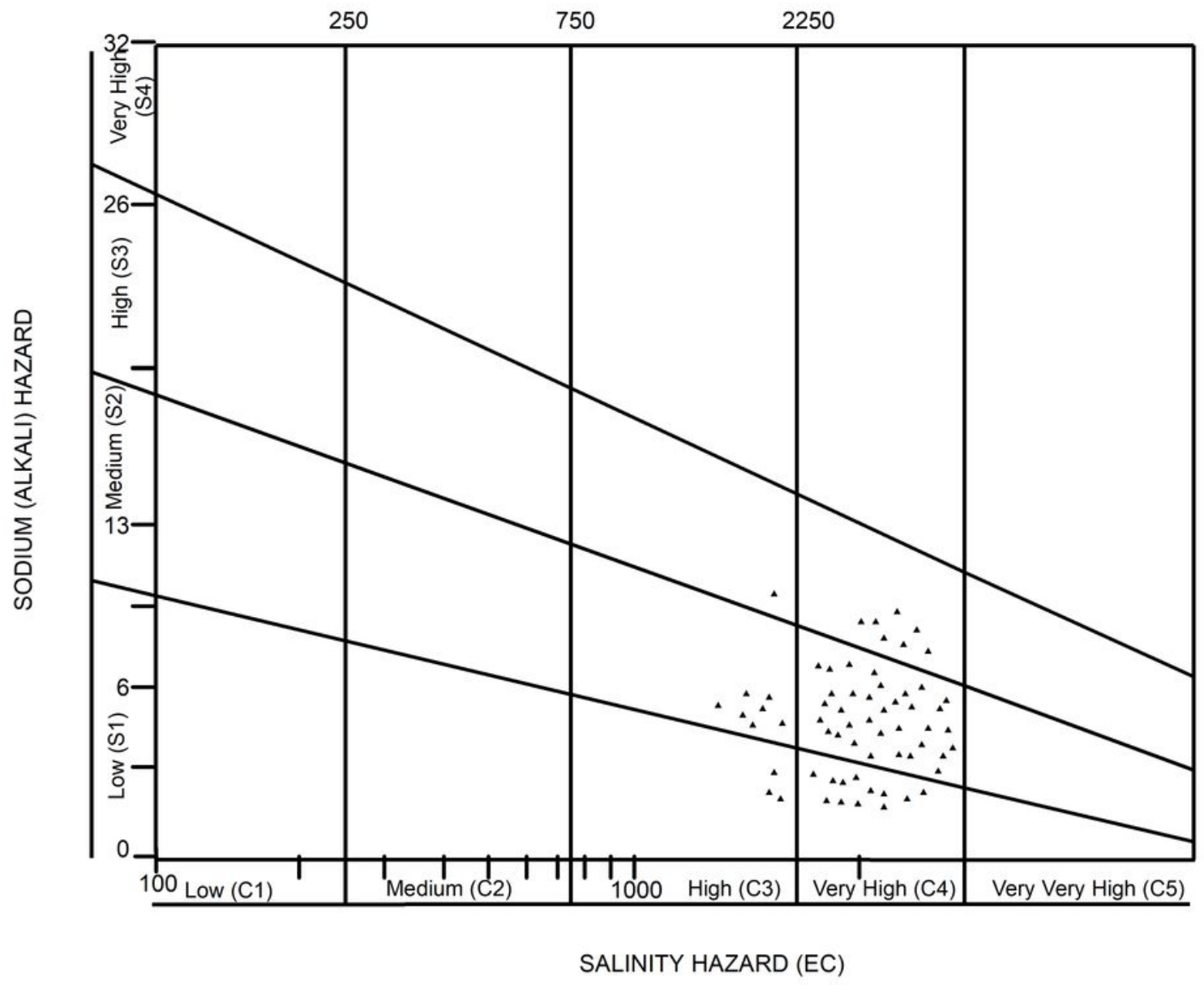

Figure 6

Wilcox diagram represents the presence of sodium content in the groundwaters 

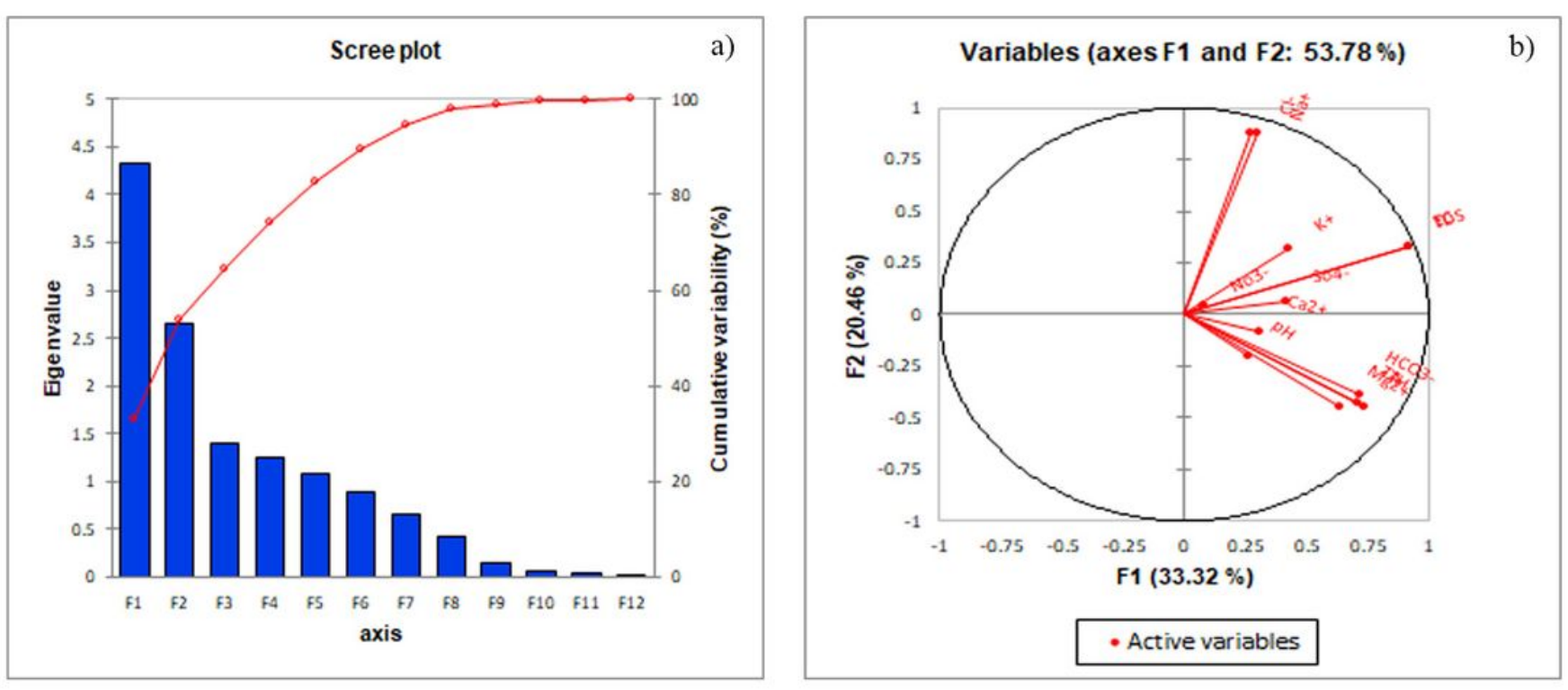

Figure 7

The suitability of groundwater for irrigation exhibiting by USSL diagram

\section{Image not available with this version}

Figure 8

Scree plot and dominance of ions in groundwaters 